\title{
Labour
}

Journal of Canadian Labour Studies

Le Travail

Revue d'Études Ouvrières Canadiennes

\section{The Raiding of Local 480: A Historic Cold War Struggle for Union Supremacy in a Small Canadian City}

\section{Ron Verzuh}

Volume 82, automne 2018

URI : https://id.erudit.org/iderudit/1058025ar

DOI : https://doi.org/10.1353/1lt.2018.0037

Aller au sommaire du numéro

Éditeur(s)

Canadian Committee on Labour History

ISSN

0700-3862 (imprimé)

1911-4842 (numérique)

Découvrir la revue

Citer cet article

Verzuh, R. (2018). The Raiding of Local 480: A Historic Cold War Struggle for Union Supremacy in a Small Canadian City. Labour / Le Travail, 82.

https://doi.org/10.1353/llt.2018.0037
Résumé de l'article

La lutte ardue pour la création de la section locale 480 du Syndicat international des travailleurs des mines, usines et fonderies à Trail, en Colombie-Britannique, a commencé en 1938. En 1944, elle avait été accréditée comme agente de négociation officielle pour les 5000 travailleurs à Consolidated Mining and Smelting Company of Canada (cm's). Mais être accrédité ne signifie pas la fin de ses problèmes. Alors même que la Seconde Guerre mondiale se terminait, les anticommunistes locaux et continentaux ont attaqué les dirigeants communistes qui avaient fondé la section locale. Parmi l'un des attaquants les plus déterminés on compte le Syndicat des Métallos. Au début de la guerre froide, la section locale 480 se préparait à se battre pendant deux ans pour se protéger des attaques des Métallos. Mandatés par le Congrès des organisations industrielles (coi) pour englober les mines, usines et fonderies en Amérique du Nord, les Métallos ont adopté une stratégie anticommuniste agressive. Au début des années 1950, lorsque ce compte-rendu commencé, la section locale 480 se battait pour sa vie. 


\section{ARTICLE}

\section{The Raiding of Local 480: A Historic Cold War Struggle for Union Supremacy in a Small Canadian City}

\section{Ron Verzuh}

Capitalizing on the Cold War politics of the early 1950s, the United Steelworkers of America (USWA), as sanctioned by the Congress of Industrial Organizations (CIO), began a North America-wide raiding campaign that included Local 480 of the International Union of Mine, Mill and Smelter Workers (Mine-Mill) at Trail, British Columbia. ${ }^{1}$ The resulting inter-union conflict from 1950 to 1952 transformed social relations in the small smelter city, home of the Consolidated Mining and Smelting Company of Canada (CM\&S), at the time one of the world's largest producers of lead and zinc. Indeed, the raid, a bold attempt to supplant the legally certified Mine-Mill local, changed the community into a battleground and enflamed an often-angry debate among workers, spouses, media, churches, and local social institutions. In retrospect, it was one of the hardest-fought but least-examined labour wars in North American history. The Trail raid offers a multilayered historical case study that invites comparisons with other resource towns across national borders, reveals how already-existing local political cultures shaped Cold War battles, identifies some of the contradictions of labour's postwar compromise, and explores the fractured nature of the Cooperative Commonwealth Federation (CCF) as it battled the Communist Party of Canada (CPC) for the allegiance of thousands of Trail smelter workers.

1. Joseph Krislov, “The Extent and Trends in Raiding among American Unions," Quarterly Journal of Economics 69 (February 1955): 145-152, 145, defines a raid as "an attempt by one union to obtain bargaining rights in a unit in which another union holds certification."

Ron Verzuh, "The Raiding of Local 480: A Historic Cold War Struggle for Union Supremacy in a Small Canadian City," Labour/Le Travail 82 (Fall 2018): 81-117. 
At the time of the raids, Trail was a single-industry town in south-central British Columbia with a population of about 12,000 inhabitants. The area had once attracted prospectors seeking gold, silver, and copper in the 1880s, but by the mid-1890s the precious metals were mostly played out, leaving nonferrous metals for more industrial-style development. Their abundance inspired Frederick (or Fritz) Augustus Heinze, one of the Butte, Montana, copper kings, to build the first smelter in 1895 as well as a small railway to carry ore from surrounding mines. The Canadian Pacific Railway, assessing the potential value of the enterprise and possibly fearing competition from Heinze's railway, soon bought it. By 1906 it had begun to expand the operation, hiring hundreds of eastern and southern European immigrants to provide cheap labour. The smelter produced essential materials for the Allies in World War I, but in 1917 the workers struck. Despite the charismatic leadership of socialist Albert "Ginger" Goodwin, the strike failed, dashing all future hope of forming a union. Instead, smelter workers accepted the employer's notion of labourmanagement cooperation in the form of a committee system. By the 1930s, however, Trail was again identified as a possible target for CIO unionization, and Arthur "Slim" Evans, the Communist leader of the 1935 On to Ottawa Trek, was assigned the task. ${ }^{2}$ The ensuing attempt to found a union and then defend it against the many anti-union forces in Trail led to a decade of conflict, marked by a fervent local anti-Communism. ${ }^{3}$

When the UswA identified Trail as a raid target in the late 1940s, it was confronting a region with a rich mining-union history, one that generated a deep culture of militancy. ${ }^{4}$ Some Trail workers - as many as 9,000 worked for CM\&S in the early 1950s - were aware of the radical heritage of the Western Federation of Miners (WFM changed to Mine-Mill in 1916). ${ }^{5}$ They regularly heard the region's socialist politicians allude to it. Men like H. W. "Bert" Herridge and independent labourite Leo Nimsick, a charter member of Local 480 , vied for smelter workers' support and got it. ${ }^{6}$ Given that history, conquering

2. See Jean Evans Sheils and Ben Swankey, "Work and Wages"!: A Semi-Documentary Account of the Life and Times of Arthur H. (Slim) Evans, 1890-1944, Carpenter, Miner, Labour Leader (Vancouver: Trade Union Research Bureau and Granville Press Ltd., 1977), for insights into Evans's role in the Trail organizing drive.

3. David Michael Roth provides a step-by-step account of the lengthy organizing drive. Roth, "A Union on the Hill: The International Union of Mine, Mill and Smelter Workers and the Organization of Trail Smelter and Chemical Workers, 1938-1945," MA thesis, Simon Fraser University, 1991.

4. For a historical assessment of the militancy, see Jeremy Mouat, Roaring Days: Rossland's Mines and the History of British Columbia (Vancouver: UBC Press, 1995); for parts of that history, see Stanley H. Scott, "A Profusion of Issues: Immigrant Labour, the World War, and the Cominco Strike of 1917," Labour/Le Travail 2 (1977): 54-78. For a different assessment, by a local historian, see Elsie G. Turnbull, Trail, A Smelter City (Langley, BC: Sunfire, 1985).

5. Estimate of workforce size drawn from “Director's Report," CM\&S Annual Report, 1951.

6. See Benjamin Isitt, Militant Minority: British Columbia Workers and the Rise of the New 


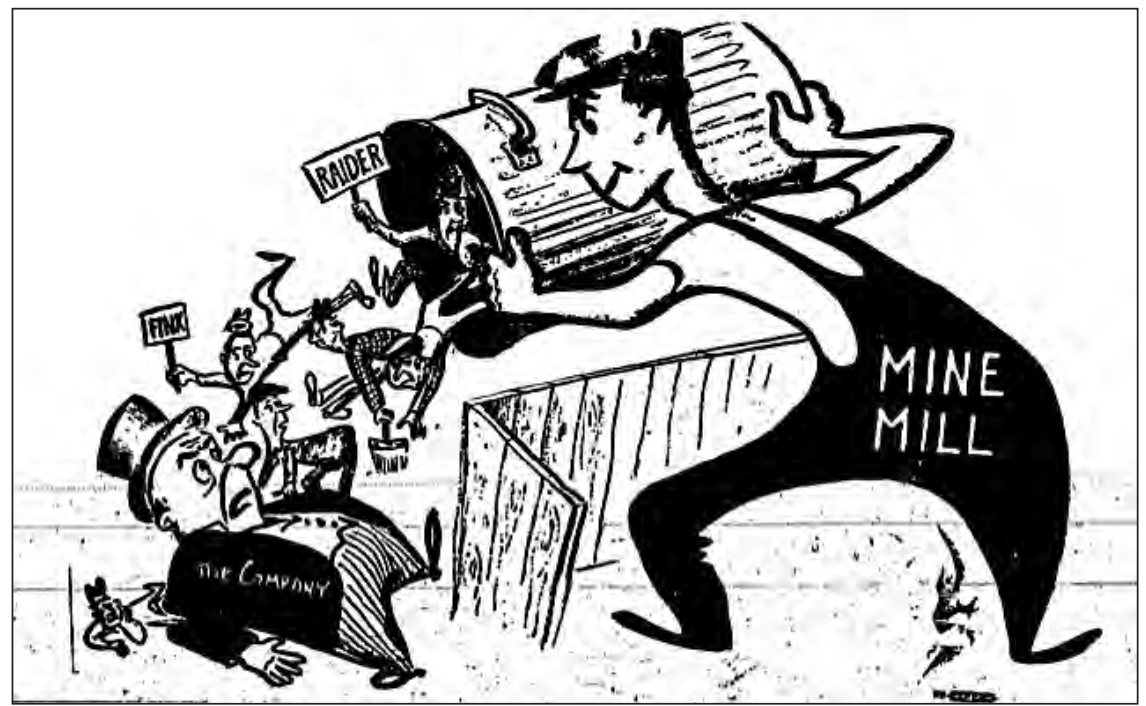

Mine-Mill dumps trash can full of raiders and finks on the company. BC District Union News, 21 January 1951, 7, call no. AW1 .R-2594, microfilm, Koerner Library, University of British Columbia. Reproduced by permission from United Steelworkers.

Trail might not be an easy task. Years of struggle with an anti-union employer and an anti-Communist company union had hardened Local 480's resolve. However, renewed challenges from within the local, and a steady flow of antiCommunist rhetoric from the local press, churches, and service clubs like the Elks and the Masons, gave the Steelworkers reason to be optimistic.

This article explores the impact of the raids on the community and their influence on the larger labour movement as it adapted to the Cold War political terrain. The UswA's political allies included the leaders of the anti-Communist Canadian Congress of Labour ( $\mathrm{CCL}$ ), the CIO's Canadian equivalent, and the CCF leadership, an equally anti-red and growing political force. In addition, the raiders could count on local anti-Communists who had erected many barriers to Local 480 over the years. As the two unions prepared for a war of words and ideas to win the allegiance of the smelter workforce, Trailites were presented with a choice: Would they support an increasingly isolated and ostracized Mine-Mill local or would they opt for the more secure future that the Steelworkers represented? The outcome of that choice, as argued here, saw the maturing of Local 480 as both a left-wing political force in the community 
and a prime example of how to resist Cold War anti-Communism. Defeating the USWA raiders was a key step in the process.

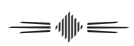

Trail was nOt AlONE in The CiO's war against its Communists, but as the largest Mine-Mill local in western Canada, it would be a jewel in the Steelworkers' crown alongside Local 598, the largest Canadian local, in Sudbury, Ontario. ${ }^{7}$ Although the historiography of union raiding is limited, there are several examples to compare with the situation that former Local 480 president Al King describes in his memoir as "fighting for our lives." ${ }^{8}$ Consider the raid on Mine-Mill Local 117 in Anaconda, Montana, about 600 kilometres southeast of Trail. As Laurie Mercier explains, the UswA made some of its most intense efforts to disrupt the union there using some of the same tactics that were employed in Trail. The comparison is apt given that both communities of the mining West share a long history of militancy under the WFM, a union that had instilled a radical fighting spirit among early union members. ${ }^{9}$ Another US community offers further opportunity for comparison. Katherine Aiken's work on Mine-Mill Local 18 at the Bunker Hill Company in Kellogg, Idaho, discusses the circumstances surrounding the Steelworker raid there. As in Trail, the Uswa had the advantage of a company union, Taft-Hartleyinspired rejection of Mine-Mill's Communist leadership, an anti-Communist movement, and an inside instigator. ${ }^{10}$

Historians have often focused on the labour purges of the 1950s as the handmaiden of raiding, and as Gary Marcuse explains, "the purges were motivated by factional fights as senior officers in the international unions took advantage of a smoke screen of anti-communism to attack left-wing rivals in the congresses and in their own unions." ${ }^{11}$ Applied to Trail, Marcuse's analysis

7. See John B. Lang, "A Lion in a Den of Daniels; A History of the International Union of Mine, Mill and Smelter Workers in Sudbury, Ontario 1942-1962," MA thesis, University of Guelph, 1970. See also Mick Lowe, The Raids: The Nickel Range Trilogy (Montreal: Baraka, 2014), a novel about the Steelworker raids in Northern Ontario.

8. Al King with Kate Braid, Red Bait! - Struggles of a Mine Mill Local (Vancouver: Kingbird, 1998), 76.

9. See Morris Wright, Takes More Than Guns: A Brief History of the International Union of Mine, Mill and Smelter Workers (Denver: Mine-Mill, 1944).

10. Katherine G. Aiken, Idaho's Bunker Hill: The Rise and Fall of a Great Mining Company, 1885-1981 (Norman: University of Oklahoma Press, 2005).

11. Gary Marcuse, "Labour's Cold War: The Story of a Union That Was Not Purged," Labour/ Le Travail 22 (Fall 1988): 200. See also Irving Martin Abella, Nationalism, Communism and Canadian Labour: The CIO, the Communist Party, and the Canadian Congress of Labour, 1935-56 (Toronto: University of Toronto Press, 1973); Reginald Whitaker and Gary Marcuse, Cold War Canada: The Making of a National Insecurity State, 1947-1957 (Toronto: University of Toronto Press, 1994). 
suggests that Local 480's Communists were part of a dissident movement that demanded more local autonomy, more democracy, and more Canadian independence - issues that collided with the Steelworker quest for an evermore-centralized union bureaucracy and its intention of usurping the bounty of union dues from large industrial workplaces like Trail.

In Vernon Jensen's account of Steelworker raids in the United States, he charges that Communist union leaders sought to bargain good contracts as a blind or camouflage for their attempts to bolster Soviet Communism. ${ }^{12}$ By contrast, Mercier and others reject the "blind" theory and lean instead toward the positive role Communists played on behalf of the rank-and-file membership. ${ }^{13}$ Rosemary Feurer further argues that Communists - in this case, those who led District 8 of the United Electrical, Radio and Machine Workers of America (UE) - saw the community focus of their organizing as "the basic starting point for a national and international movement for social transformation." 14 In that vein, comparisons with Trail, particularly concerning the raids, are instructive in determining how much ommunism might or might not have obstructed trade unionism. Other US scholars reveal conflicting views. For example, CıO historian Robert Zieger, similar to Jensen, argues that the purges and concomitant raiding were justified as an "initial repudiation of the Stalinoid impulse" even though they "did nothing to advance the cause of the industrial working class and invited employers' counterattacks." 15 Others disagree with this view. ${ }^{16}$ Surprisingly few scholars, however, mention the prolonged Cold War contest to win Local 480.

12. Vernon H. Jensen, Nonferrous Metals Industry Unionism, 1932-1954: A Story of Leadership Controversy (New York: Cornell University Press, 1954).

13. Laurie Mercier, “'Instead of Fighting the Common Enemy': Mine Mill versus the Steelworkers in Montana, 1950-1967," Labour History 40, 4 (1999): 459-480. See also Laurie Mercier, Anaconda: Labor, Community, and Culture in Montana's Smelter City (Urbana: University of Illinois Press, 2001).

14. Rosemary Feurer, Radical Unionism in the Midwest, 1900-1950 (Urbana: University of Illinois Press, 2006), xvii.

15. Robert H. Zieger, The CIO 1935-1955 (Chapel Hill: University of North Carolina Press, 1995), 376.

16. Those in disagreement include Steve Rosswurm, ed., The CIO's Left-Led Unions (New Brunswick, New Jersey: Rutgers University Press, 1992); Karl Korstad, "Black and White Together: Organizing in the South with the Food, Tobacco, Agricultural \& Allied Workers Union, 1946-1952," in Rosswurm, CIO’s Left-Led Unions, 93; Michael K. Honey, “Operation Dixie, the Red Scare, and the Defeat of Southern Labour Organizing," in Robert W. Cherny, William Issel, and Kieran Walsh Taylor, eds., American Labour and the Cold War: Grassroots Politics and Postwar Political Culture (New Brunswick, New Jersey: Rutgers University Press, 2004). Several scholars agreed that the raids substantially weakened the labour movement, including Bert Cochran, Labour and Communism: The Conflict That Shaped American Unions (Princeton, New Jersey: Princeton University Press, 1977); Art Preis, Labour's Giant Step: Twenty Years of the CIO 1936-55 (New York: Pathfinder, 1994); David Caute, The Great Fear: The Anti-Communist Purge under Truman and Eisenhower (New York: Simon \& Schuster, 
IN THE LEAD-UP TO THE RAID, it seemed that the USWA could rely on the many allies mentioned earlier, but there was at least one potential roadblock to success that raid planners had underestimated: Harvey Murphy. A lifelong Communist, Murphy had captured smelter workers' loyalty after guiding the local to BC Labour Board certification in the summer of 1944 and had acted as Local 480's head negotiator from then on. In April 1948, however, raid planners were buoyed by an event that promised to further strengthen their anti-Communist strategy. At a drunken banquet that spring in Victoria, British Columbia, Murphy had insulted the CCL executive, including some Steelworker leaders, chastising them for refusing to assist Mine-Mill international president Reid Robinson when he was about to be deported from Canada as a suspected Communist. King recalled that Murphy - in what is known in labour circles as the "Underpants Speech" - "told the full meeting that if Mosher was going to kiss the boss's ass, he better be sure to pull his pants down first." 17 The ill-advised outburst led to Murphy's two-year suspension as vice-president of the BC Federation of Labour. It was, as some observers well understood, a perfect excuse for the red labour purges that would open the door for the UswA raids. ${ }^{18}$

In March 1949, the raiders were again helped by the firing of four Local 480 members, among them Communists Jack Scott, a decorated war hero, and Gar Belanger, the local's first president, for distributing articles in the Communist Pacific Tribune that denigrated the CM\&S. ${ }^{19}$ Anti-Communist Local 480

1979); Judith Stepan-Norris and Maurice Zeitlin, Left Out: Reds and America's Industrial Unions (Cambridge: Cambridge University Press, 2003); Ellen Schrecker, "Labour and the Cold War: The Legacy of McCarthyism," in Cherny, Issel, and Taylor, American Labour, 7-24. American scholarship also includes several Cold War studies relevant to the Local 480 raid: Anne Fagan Ginger and David Christiano, "Mine, Mill, and Smelter Workers: The Salt of the Earth," in Anne Fagan Ginger and David Christiano, eds., The Cold War Against Labour: An Anthology (Berkeley: Meiklejohn Civil Liberties Institute, 1987), 592-614; Roger Keeran, "The Communist Influence on American Labor," in Michael J. Brown, Randy Maltin, Frank Rosengarten, and George Snedeker, eds., New Studies in the Politics and Culture of U.S. Communism (New York: Monthly Review Press, 1993), 192. See also Mark Naison, "Communism from the Top Down," Radical History Review 32 (1985): 97-101; for a review of anti-Communist history, see Harvey Klehr, The Heyday of American Communism: The Depression Decade (New York: Basic Books, 1984).

17. King, Red Bait!, 76.

18. For one account of the events, see Abella, Nationalism, Communism, 121. Among several other more anecdotal recollections is the remembrance of Howard White, A Hard Man to Beat: The Story of Bill White, Labour Leader, Historian, Shipyard Worker, Raconteur: An Oral History (Vancouver: Pulp Press, 1983), 168.

19. “C.M.\&S. Sacks Four Local Employees; Union Orders Probe,” Trail Daily Times (hereafter TDT), 1 April 1949; Bruce Mickleburgh, "Consolidated Prepares an Inside Job," Pacific Tribune (hereafter $P T$ ), 11 March 1949; “The War Scare Pays Off - For Consolidated," PT, 18 March 


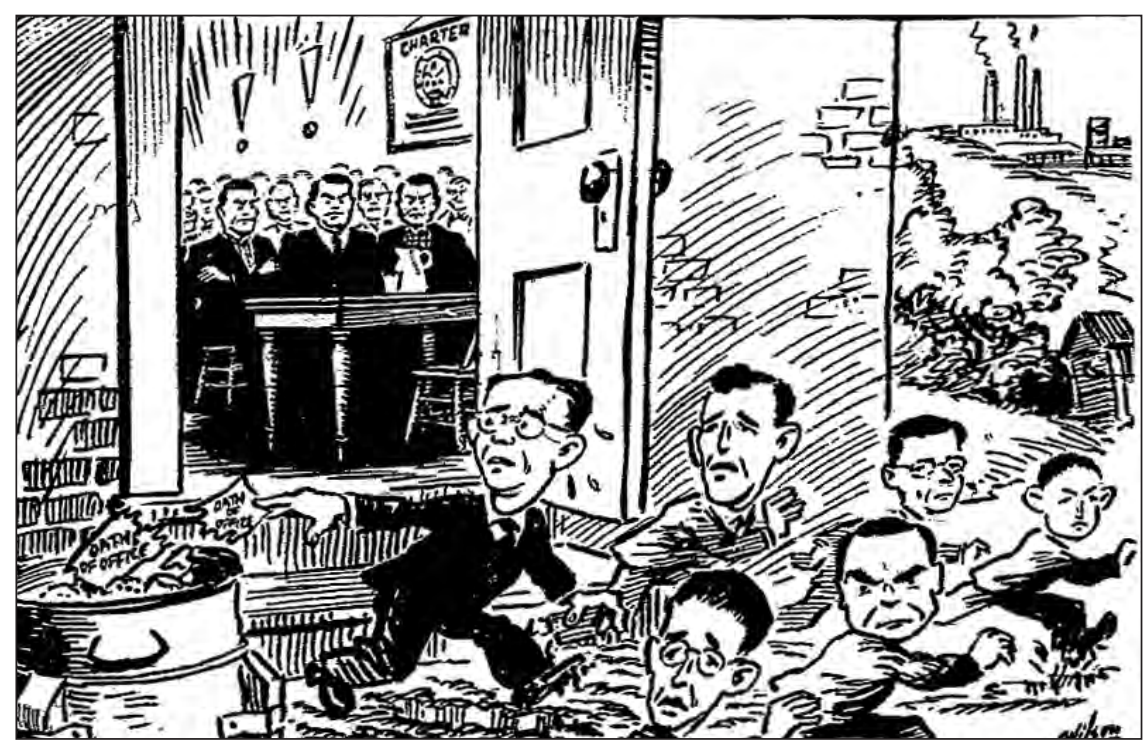

Claire Billingsley and his executive renounce Local 480 and flee to Steel.

BC District Union News, 7 March 1950, 8, call no. AW1 .R-2594, microfilm, Koerner Library, University of British Columbia. Reproduced by permission from United Steelworkers.

president Claire Billingsley, first elected in 1947 and later entrenched as the Steelworkers' inside ally, did not hurry to defend Murphy or the fired members. The unwise speech and the firings could only work in the raiders' favour, but would they be enough to steer the local membership to the raiding union?

Significantly, the raiders enjoyed the benefit of an anti-red employer. CM\&S president Selwyn G. Blaylock had long been on record as fearing "Socialists and Communists" and harbouring an "intense dislike of unions." ${ }^{20}$ Although Blaylock died in November 1945, his anti-union and anti-Communist views were widely accepted by the CM\&S managers that followed him. ${ }^{21}$ In addition, Prime Minister Louis St. Laurent had shown a willingness to emulate some of the US Communist witch-hunting tactics that came with passage of the anti-Communist Taft-Hartley Act in $1947 .{ }^{22}$ In fact, St. Laurent needed

\section{9.}

20. Martin Robin, Pillars of Profit: The Company Province, 1934-1972 (Toronto: McClelland \& Stewart, 1973), 40.

21. David Bercuson, Fools and Wise Men: The Rise and Fall of the One Big Union (Toronto: McGraw-Hill Ryerson, 1978), 190.

22. Several studies analyze such state tactics. Two notable ones are Gary Kinsman, Dieter K. Buse, and Mercedes Steedman, eds., Whose National Security?: Canadian State Surveillance and the Creation of Enemies (Toronto: Between the Lines, 2000), and Larry Hannant, The Infernal Machine: Investigating the Loyalty of Canadian Citizens (Toronto: University of 
no coaching from the Americans, for Canada's Cold War was not simply a replica of what was happening down south. As Richard Cavell has noted, "it was actively produced here." ${ }^{23}$ Thus, with Local 480 Communists beset by a red-baiting challenger, anti-Communists preaching from local pulpits, public denouncements by CM\&S management, daily editorial whippings by the pro-company anti-Communist Trail Daily Times, and the negative legacy of Murphy's Victoria speech, the Uswa was ready to pounce.

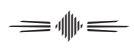

THE RAID BEgAN IN EARNEST ON 9 February 1950 with a full-page advertisement in the Times. Its message played on the insecurities associated with Mine-Mill being expelled from the CCL because of its Communist leadership. The raid leaders who signed the ad stated that the early principles of Local 480 had been

warped and distorted by a top leadership completely dominated by outside political influences. ... It has failed to unite those who still remain within its ranks. ... It has lost the respect of other unions and the community. It has already been expelled from the Canadian Congress of Labor. We are convinced that it will be shortly expelled from the C.I.O. It is becoming a weak, independent union. ${ }^{24}$

In essence, the ad declared that to remain in the Canadian labour movement, Local 480 members had to accept the USWA as their new bargaining agent. It advised shop stewards to abandon the Mine-Mill local. Billingsley and his executive resigned en masse. In effect, the local was being asked to commit suicide and it seemed like it might succeed. Now the number one anti-red "bad boy," as Billingsley saw himself, was also about to be "branded all across Canada as being a traitor." ${ }^{25}$ Murphy called the raid "a most disgusting exhibition of treachery." ${ }^{26}$ The company seemed to give the UswA its blessing for, as King saw it, management was allowing these "traitors to their union to sign up members on company time." ${ }^{27}$ King further explained the process:

When Billingsley and the Steel raiders signed up our members, they asked them to sign two things: one was to the company, revoking their dues checkoff to Local 480 . ... The

Toronto Press, 1995).

23. Richard Cavell, ed., Love, Hate, and Fear in Canada's Cold War (Toronto: University of Toronto Press, 2004), 6.

24. "We're Staying with CIO-CCL," TDT, 9 February 1950.

25. Claire Richard Billingsley, interview by Richard Bell, 17 August 1983, Trail, BC, item A А А 5673 , sound recording, Fonds PR-1880 - West Kootenay Cultural Society Oral History Collection, BC Archives, Royal BC Museum, Victoria, BC (hereafter BC Archives). Transcription prepared by Richard Bell.

26. "Murphy Replies," TDT, 9 February 1950.

27. King, Red Bait!, 81. 
second thing our members were asked to sign was a Steel membership card - but no money changed hands. The law required that a minimum one dollar be paid whenever anyone signed an application card as a union member. ${ }^{28}$

That oversight and the Steelworkers' failure to administer an oath on the signing of a union card would later prove to be fatal mistakes for the raiding union.

A week after the Times ad appeared, the CIO joined the CCL in expelling Mine-Mill, bringing to a head years of red-baiting and name calling. Billingsley was elated. Speaking to the Times as "provisional president," he said the expulsion confirmed his own actions and proved that his former union was "an utterly powerless instrument for collective bargaining or local union service." ${ }^{29}$ His comments triggered an editorial war between the two competing unions, with the Times taking the Steelworkers' side. Among the many letters, Local 480 member Kitch Bannatyne compared the executive resignation to Japan's "sneaky attack on Pearl Harbor." 30

The now leaderless local's first move was to appoint an administrator to assess raid damage. Veteran Local 480 member Jack Gordon was chosen and quickly convened a meeting in the Legion Hall, on 10 February. Murphy told the gathering of hundreds of confused members that Local 480 was far from dead. Gordon then called for nominations to fill the vacated executive positions. King recounted what followed:

All I can remember is a chorus of voices. Then John Gordon said, "We haven't got time to conduct a ballot, so for each position, I'm going to send you down to the back." There was a big washroom back there, the only other large room in the place. So Gordon says, "You eighteen go back into the toilet and when you come out of there, whoever you decided on among yourselves will be the new president." 31

King was thus elected president and the new Local 480 leadership, dubbed the "Shithouse Executive," was charged with mounting a counterattack against Billingsley and the Steelworker raiders. ${ }^{32}$ Their first concern was an empty bank account, so they appealed for help from other Mine-Mill locals. Then they had to win back the support of the membership, and they had to do it fast. Bargaining was to begin in June, just four months away, and if the union did not have a majority signed up within 60 days of negotiations, the company could file to decertify it. At the same time, the Steelworker raiders could still be in a position to apply for certification.

As the reality of the raid struck home, Local 480 loyalists and dissenters alike revealed a deep divide leading up to and during the raid years. King thought

28. King, Red Bait!, 79.

29. "Local President Praises CIO Action in Expelling Mine, Mill," TDT, 16 February 1950.

30. "Mine-Mill," TDT, 16 February 1950.

31. King, Red Bait!, 80.

32. King, Red Bait!, 80. 
the "entire world" had turned against the local: "Clearly, the defecting executive expected a swift and complete elimination of Local 480, so they wanted to hurry up the legal process, while we as the new executive fought for time, using anything to delay so we could gather support and fight back." ${ }^{33}$ Others were equally stunned by the animosity the raid had unleashed. As John Page recalled, "the guys were going crazy." He supported the Steelworkers, saying that Murphy was "a good talker but that's all they did. Just got us nickels." ${ }^{4}$ George Bishop also found Mine-Mill wanting. We "were hard on Mine-Mill because of all the things that they'd said they were going to go for and then had to back down on." ${ }^{35}$ Cliff York recalled that the members were angry because bargaining had gone badly the year before. "There was a lot of dissension at the time," he noted. "It was one of those civil wars that was not good." 36 Richard Gop argued that Murphy's CPC membership was a problem: "I don't think that done Mine-Mill much good in a place like this," he recalled. ${ }^{37}$ Murphy's Communist comrade Gar Belanger remembered the raid being a "rough struggle" and a costly one, with both unions "spending a lot of workers' money" and "getting nowhere." He concluded that "the brass at Cominco must have been sitting back and having a great laugh at the unions decimating one another." 38 For Communist shop steward Al Warrington, the raid came during personal hard times. Nevertheless, he refused to join the deserting shop stewards and was proud that his "plant was 100 per cent Mine-Mill." 39

As the raid continued, Mine-Mill's fight-back campaign included an attempt to get a BC Supreme Court injunction against the Uswa for attempting to name the raiding union the Trail and District Smelterworkers' Union Local 4281. The similar numbers were intended to cause even more confusion. ${ }^{40}$ Other Local 480 defence tactics included radio broadcasts by union members. In one, Mine-Mill's Gordon blamed the smouldering remnants of Blaylock's old company union for splitting the union through "deliberate falsehoods and

\section{King, Red Bait!, 82-83.}

34. John Page, interview by Richard Bell, 19 July 1983, Trail, BC, item A A AB5670, sound recording, BC Archives.

35. George Bishop, interview by Richard Bell, August 1983, Trail, BC, item AAAB5672, sound recording, BC Archives.

36. Clifford York, interview by Richard Bell, 15 August 1983, Trail, BC, item A A AB5674, BC Archives.

37. Richard Gop, interview by Richard Bell, 27 June 1983, Trail, BC, item AA AB5667, BC Archives.

38. Garfield Belanger, interview by Richard Bell, 29 June 1983, Kaslo, BC, item A A A B5668, BC Archives.

39. Albert Warrington, interview by Richard Bell, 29 June 1983, Kaslo, BC, item A A AB5677, BC Archives.

40. “Trail Union Battle Moves to Supreme Court,” TDT, 15 February 1950. 


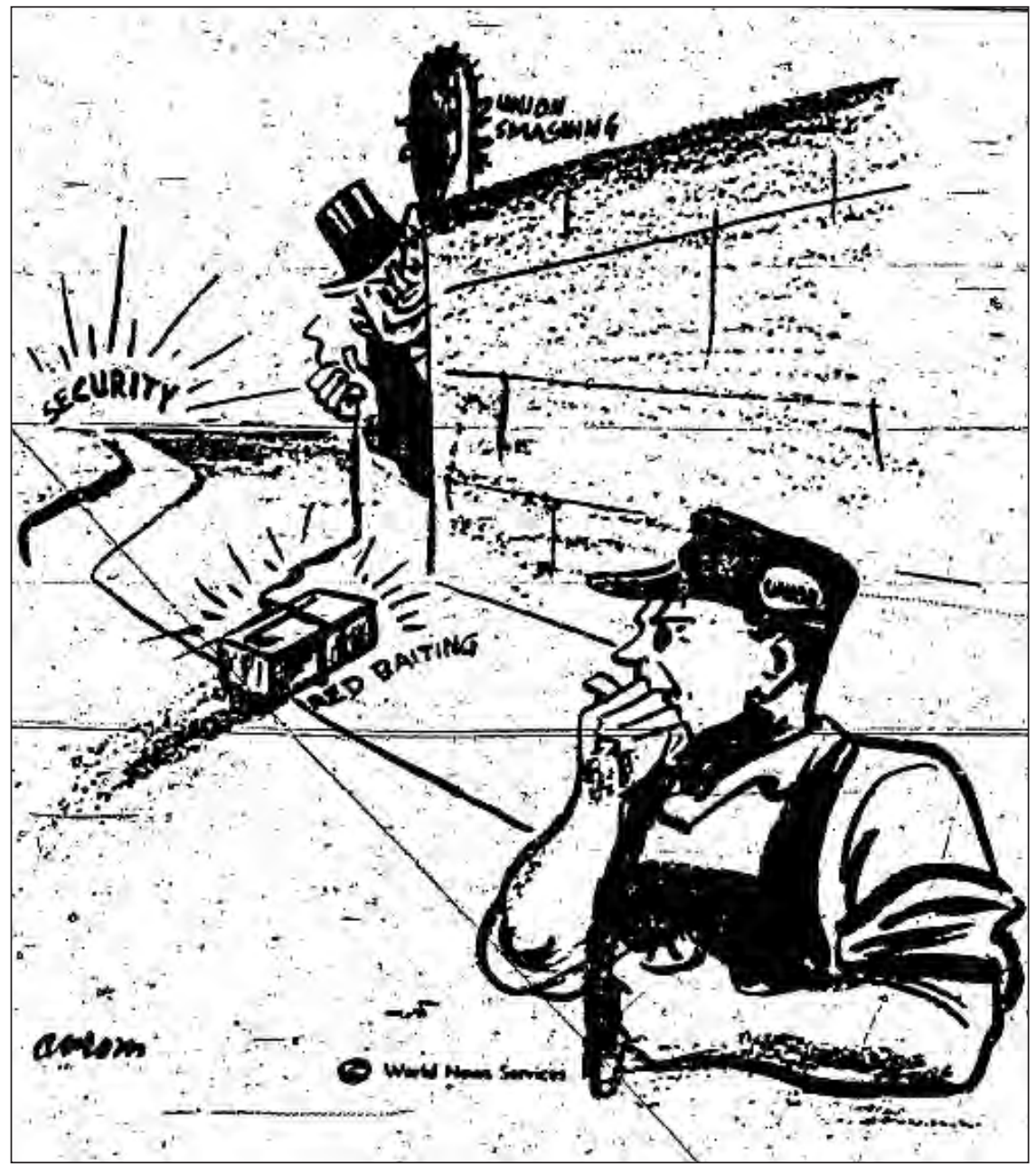

Local $\mathbf{4 8 0}$ faced the double threat of union smashing and red baiting.

BC District Union News, 22 January 1947, 7, call no. AW1 .R-2594, microfilm, Koerner Library, University of British Columbia. Reproduced by permission from United Steelworkers.

misrepresentation." ${ }^{41}$ Former Local 480 president Percy Berry told the radio audience that the raid was a "dastardly act" and praised the Local 480 loyalists as

men who balk at condoning treachery, deceit, men who know full well there is an honorable and decent way to settle all differences, without turning worker against worker, wife against

41. “Same Old Company Union Gang Goes Steel...," BC District Union News (hereafter DUN), 7 March 1950, 3. 


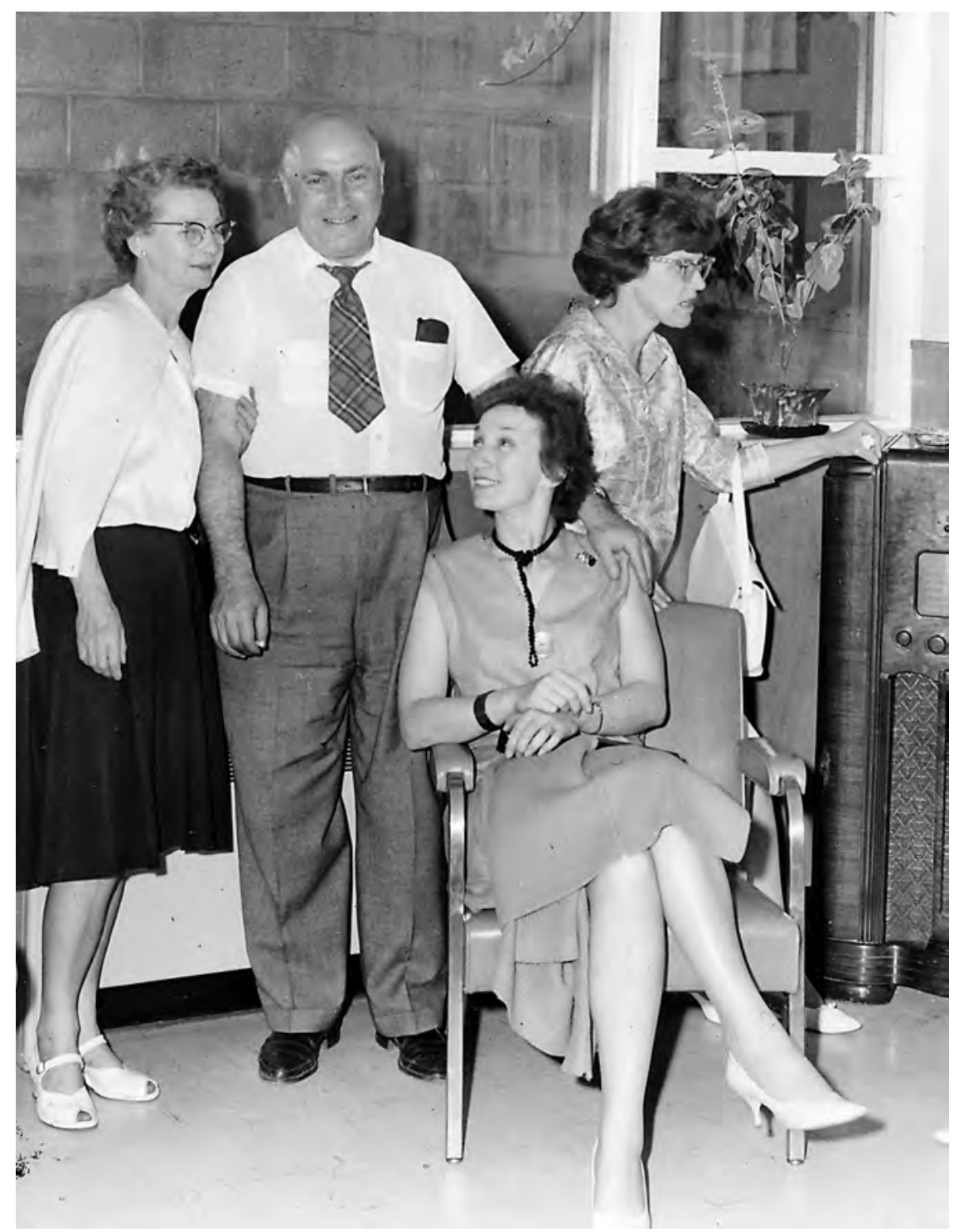

Harvey Murphy with ladies auxiliary members. Trail's LA Local 131 fought passionately against the Steel raiders.

Local 480 Archives, Trail, BC. Courtesy of USW Local 480. 
husband, brother against sister and home against home and setting a whole community aflame to satisfy the greedy ambitions of a few. ${ }^{42}$

Members of Ladies Auxiliary Local 131 also joined in with supportive broadcasts, laying to rest the notion that auxiliaries were apolitical groups limited to serving food at union meetings and holding whist parties and tea dances. The women came forward to defend the local against the Steelworkers, but their actions against the anti-red union may also have challenged the view promoted by churches, governments, and the media that a full-time female homemaker is "essential to a happy, socially productive family." Julie Guard stresses that for many anti-Communists, maintaining a healthy society "depended on the presence of a stay-at-home mother." This philosophy "was understood to be an effective antidote against opportunistic political ills, the most virulent of which was communism." ${ }^{33}$ The auxiliary proved otherwise.

In a further defensive manoeuver, the Mine-Mill combatants purchased ads in the Times to match the Steelworker ads, but their effect may have been somewhat neutralized by the Times's raid coverage. In one front-page article, for example, editor William Curran declared that "CıO Steel Claims Edge on Mine-Mill." In the accompanying article, Billingsley stated that Mine-Mill no longer had the "moral right" to represent the smelter workers and complained about "the torrent of personal abuse and half-truths." 4

Addressing a mass meeting in Trail on 19 February, International MineMill president John Clark attacked the CIO-CCL raiders, calling them "worse than "Pinkertons and [the] paid stool pigeons and union busters of early labour history in North America." Mine-Mill District 8 board member Bob Carlin, visiting from Sudbury, Ontario, "compared the CIO-CCL tactics with those of Hitler" and urged Trail women to "stand behind their husbands." International executive member Chase Powers called the Steelworker tactics "those of 'cannibals" and hinted that they were similar to "Mussolini's telling the Ethiopians he was going to "liberate' them." ${ }^{45}$ Two days later, another full-page Steelworker ad stirred even angrier cries from Mine-Mill. In a series of carefully selected excerpts from a CiO committee report, the ad argued that Mine-Mill leaders had led the members down "their evil path." ${ }^{46}$

From 20 to 22 February, Mine-Mill convened a national convention in Trail attended by International Mine-Mill leaders and other union dignitaries. Two Tacoma, Washington, Mine-Mill convention guests were turned away at the

42. "Percy Berry Broadcasts [sic] Reflects General Opinion of Trail Populace," DUN, 14 August 1950,8 .

43. Julie Guard, "Women Worth Watching: Radical Housewives in Cold War Canada," in Kinsman, Buse, and Steedman, Whose National Security?, 77.

44. Billingsley interview; “Cio Steel Claims Edge on Mine-Mill,” TDT, 22 February 1950.

45. “'Raider' Tactics Blasted at Mass Meeting,” TDT, 20 February 1950.

46. “Why C.I.O. Expelled Mine, Mill,” TDT, 21 February 1950. 
Paterson, Washington, border crossing when customs authorities there said they lacked proper credentials. Secret police reports suggested that they were a "diversionary action" meant to hide the presence in Trail of International Mine-Mill secretary-treasurer Maurice Travis, a Communist who had been banned from entering Canada. He had arrived in Trail ostensibly to attend the convention, but in fact was there to assist with the fight against the raiders. Billingsley helpfully guided police to where Travis was staying and cheered when they escorted Travis to the border. Billingsley later remembered thinking that "they should have thrown the book at him." By making Travis's secretive presence known, he may have hoped that it would have "a salutary effect" on the delegates and generate a "spirit of rebellion ... [that] could well flourish." At least that was the assumption of Constable J. G. E. Murray of the Grand Forks, $\mathrm{BC}$, detachment, one of several RCMP officers assigned to monitor the raid. ${ }^{47}$

In Mine-Mill's provincial organ, the BC District Union News, Murphy called the Billingsley group a "clique," "traitors," "seceders," and "ratting shop stewards," claiming that many of them were from "the old company union gang." He said the CCL leadership was "guilty of treachery." ${ }^{\text {" }} \mathrm{He}$ then issued this rallying cry: "Remembering our martyred dead, we fight to see these traditions live." ${ }^{" 49}$ Murphy condemned raid leaders, arguing that "in their mad struggle for power the Charlie Millards, [Aaron] Moshers, [Bill] Mahoneys, etc., care nothing for the conditions of the workers." 50

Millard, the Canadian Steelworker director who orchestrated the raid, was a religious man who saw Communists "as his most formidable opposition." As Laurel Sefton MacDowell notes in a brief biography, "Millard would prove equal to their challenge," adding, "for while he carried a Bible in one hand, he held a hatchet in the other." ${ }^{11}$ Mosher, the CCL president who condoned the raid, had long been an anti-red, as was Mahoney, the CCL district director who oversaw raid activities in Trail. All of them intensely disliked Murphy, who boldly declared himself "the reddest rose in Labour's garden." ${ }^{52}$ The "etc." in Murphy's list of raid leaders above referred to Herbert Gargrave, a CCF MLA (Mackenzie District) who had been unseated in the 1949 BC election. He was

47. Constable J. G. E. Murray, "Subversive Activities of I.U.M.M.\& S.W.," 27 February 1950, obtained from the Canadian Security and Intelligence Service (CSIS) through Access to Information requests.

48. "Loyal Workers Repulse Trail Seceders, Raiders, New Officers Take Over," DUN, 7 March 1950.

49. “Trail Meeting Blasts CIO-CCL Policy of Ruin,” DUN, 7 March 1950.

50. “What Trail Means,” DUN, 7 March 1950.

51. Laurel Sefton Macdowell, "The Career of a Canadian Trade Union Leader: C.H. Millard 1937-1946," Industrial Relations 43, 3 (1988): 614.

52. Stephen L. Endicott mentions this phrase but does not source it. Endicott, Raising the Workers' Flag: the Workers' Unity League of Canada 1930-1936 (Toronto: University of Toronto Press, 2011), 126. 


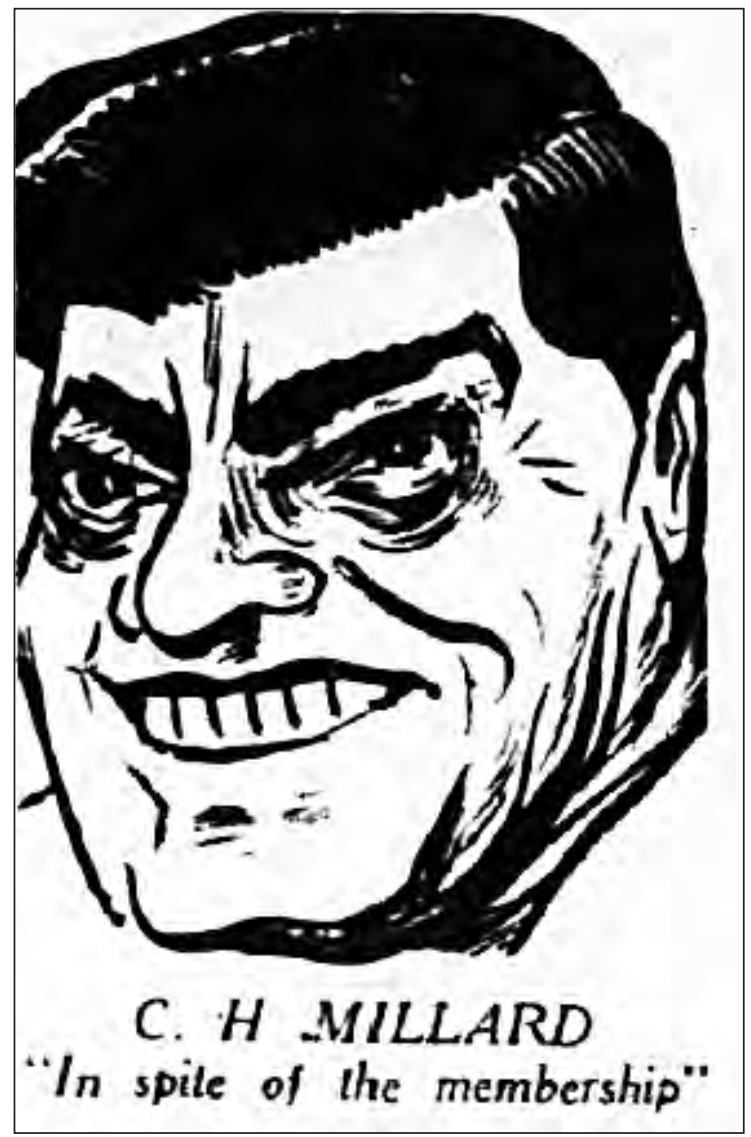

The Communist Pacific Tribune published this image with a critical profile of Steel raid leader Charlie Millard.

Pacific Tribune, 12 May 1950, 4, Pacific Tribune Collection, Special Collections and Rare Books, Simon Fraser University Library.

tasked with coordinating the raid in Trail. Al Warrington, Local 480's grievance chair, also jumped to his local's defence, with a letter that chided those who discredited Mine-Mill as "Communist" and advised his fellow union members not to follow "these Iscariots." 53

In March, the raid escalated with both unions buying at least six ads each. The uswa continued to employ its red-baiting strategy, quoting an article from the Communist Pacific Tribune regarding Canada's nuclear power program. The raiding union argued that "operations in Trail are vital to the national security of Canada" and stressed that "now you can see ... why the Communist Party is throwing ALL its resources behind the Mine, Mill Union." 54 As the month wore on, tempers flared anew. After a kerfuffle at the Legion Hall, King was charged with assault and battery. The incident involved an altercation

53. “Kimberley Knows the Score," DUN, 7 March 1950.

54. “The Cat's Out of the Bag," TDT, 24 March 1950. 


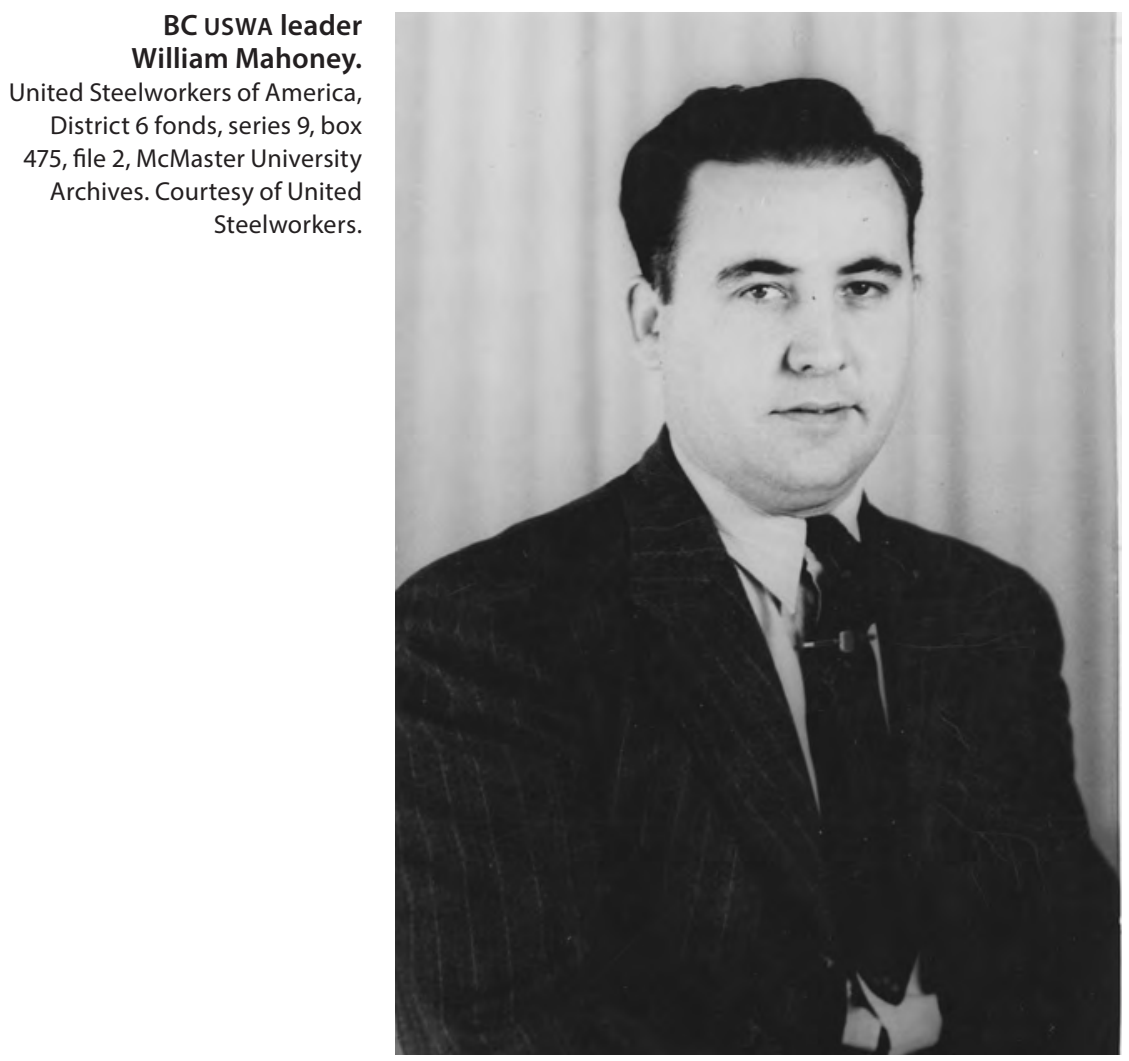

with Charles Bradbury, a local lacrosse player and member of the newly formed rival uswa local. As King recalled, Bradbury had said to Murphy, "Get out, you Communist sonofabitch. I shot people like you in the Second World War." King, standing right behind Bradbury, had replied, "And maybe I shot githorns like you." They went outside and "I put Bradbury in the hospital," King remembered. ${ }^{55} \mathrm{He}$ was convicted and given a suspended sentence. It was a relatively minor incident compared to what was happening in labour's Cold War south of the border, but the affair had two possible consequences. First, it may have bolstered Mine-Mill's fortunes in that some members would have respected King for his masculine toughness, an image that dominated in a male-breadwinner society like Trail's. Alternatively, Steelworker supporters might have viewed it as substantiating claims of insensitive and violent communist behaviour.

Billingsley and Murphy traded arguments about the raid later that spring, but soon top CCL officials were also engaging in raid-inspired combat, when Pat 
Conroy and Silby Barrett, both of them United Mine Workers (UMw) organizers, argued about who should have jurisdiction over the Trail workers. Barrett wanted Conroy to award jurisdiction over Warfield chemical workers to the UMw, but Conroy was refusing to split up the Mine-Mill membership prize. ${ }^{56}$ Meanwhile, Murphy had challenged Billingsley to a debate, but Billingsley backed away - probably a wise choice since Murphy was known as "one of the most popular speakers for a generation of the radical left in Canada." ${ }^{57}$ Charges of "lies" and countercharges of "red" infiltration ran rampant throughout the campaign. King argued that Communists were a minority of three on his executive. "We never tried to sign anybody up to the Communist Party through the union," he recalled, declaring that the USWA was "using the red bogey and also trying to make it appear that Harvey Murphy is the issue. ${ }^{\prime 58}$ He referred to the federal election of Liberal Party candidate Jim Byrne, a Mine-Mill Local 651 executive officer in Kimberley, BC, as an example of how Mine-Mill allows "each individual member to retain their individual political freedom." Stating that his executive members were long-time residents of Trail - many were veterans like King - and that many had years of seniority on the Hill, he stressed that "the issue is trade unionism" and added that "we intend to keep this union free from being used by any political clique or party." 59

The war of insults carried on even after 10 March when the Steelworkers' application to represent smelter workers went to the BC Labour Relations Board (LRB). ${ }^{60}$ Late that month, Local 480 announced that it was demanding a seventeen-cent raise when the collective agreement expired on 1 June. ${ }^{61} \mathrm{It}$ was an easily justified demand given that the CM\&S (renamed Cominco) had announced a $\$ 41.5$ million profit for $1949 .{ }^{62}$ In mid-April, Constable Murray reported a lull in the "union war," adding that "information persists that this woman is in Trail - 'master-minding' [the] Mine Mill campaign." The woman was Communist militant Becky Buhay, head of the CPC's women's department and a "pioneer socialist feminist in Canada." ${ }^{3}$ By late April the disunifying potential of the USwA raid again attracted the notice of Ladies Auxiliary Local 131. "When the raiders come your way as they surely will, I hope you are united and strong enough to cast them aside," advised Communist Mathilda

56. "Conroy-Barrett Battle Looms," TDT, 7 March 1950.

57. "Murphy Asks Debate with Steel President," TDT, 18 March 1950. See also Endicott, Workers' Flag, 111.

58. King, Red Bait!, 84.

59. “To the Citizen's $[s i c]$ of Trail and District," TDT, 21 February 1950.

60. "Steel Requests Certification," TDT, 10 March 1950.

61. “Mine-Mill After 17c Increase," TDT, 29 March 1950.

62. “Cominco Profits Hit \$41,588,033," TDT, 13 April 1950.

63. Endicott, Workers' Flag, 161. 
"Tillie" Belanger in The Union, Mine-Mill's international newspaper, "for they are nothing more than vultures out to destroy you and Mine-Mill." A practising nurse and spouse of the now fired Gar Belanger, she wholeheartedly shared her spouse's political views:

raiding of one group of workers by another is about the lowest form of life that I can imagine. It not only tends to disunite the working class but strengthens the ruling class to the point where it can further exploit and destroy the Trade Union Movement and the freedom of the working class. ${ }^{64}$

Police observers also noted that three other developments had strengthened Local 480's defences against the Steelworker raiders. The first involved the hiring of F. E. "Buddy" DeVito, a veteran and member of Trail's ItaloCanadian community, as a temporary International Mine-Mill representative. Constable Murray noted that DeVito "takes the stand that I.U.M.M. \& S.W. is right in this dispute and that it has benefitted the City of Trail." ${ }^{65}$ Second, Father Clarence Duffy, representing the Canadian Peace Congress, a national peace advocacy group, advised Local 480 members to "stand fast' against the inroads of 'raiding' so-called labour organizations and that 'the good would win out in the end." He then "gave his blessing" to Local $480 .{ }^{66}$ The third development involved Liberal MP Jim Byrne, who also took Local 480's side in the Trail raid. The Kootenay East member turned on CCF MP Angus MacInnis, a founder of the CCF and a devoted red-battler since the party's founding in $1932 .{ }^{67}$ Byrne told MacInnis in the House of Commons, "my union steadfastly refused to become a part of or join the political machine of the CCF Socialist party." The allusion to a CCF-CCL cabal operating against workers' interests in Trail and Kimberley could not have been made more clear to MacInnis, who countercharged that Byrne was "parroting Harvey Murphy." 68

In early May, Constable Murray reported that Mine-Mill's campaign was riddled with "personal attacks" and "bluffing." He then listed ten people who had supported Mine-Mill, including Father Duffy and high-level CPC leader Charles Sims. ${ }^{69}$ The Steelworker ad blitz and Mine-Mill's response continued, with the USWA claiming in one ad to have negotiated the "Greatest Wage Increase Gained in Canada This Year." It had won a thirteen-cent-an-hour wage hike for its Hamilton, Ontario, local. ${ }^{70}$ Meantime, the Times's new editor,

64. “Calls Raiders 'Vultures'," The Union, 24 April 1950.

65. Constable Murray, "Subversive Activities," 14 March 1950.

66. Constable Murray, "Subversive Activities," 13 March 1950.

67. For a full discussion of the CCF's drift towards social democracy, see James Naylor, The Fate of Labour Socialism: The Cooperative Commonwealth Federation and the Dream of a WorkingClass Future (Toronto: University of Toronto Press, 2016).

68. "Byrnes [sic] Backs Mine-Mill in House, PT, 7 April 1950.

69. Constable Murray, "Subversive Activities," 2 May 1950.

70. “Labour Wins 13c an Hour Increase!” TDT, 3 May 1950. 


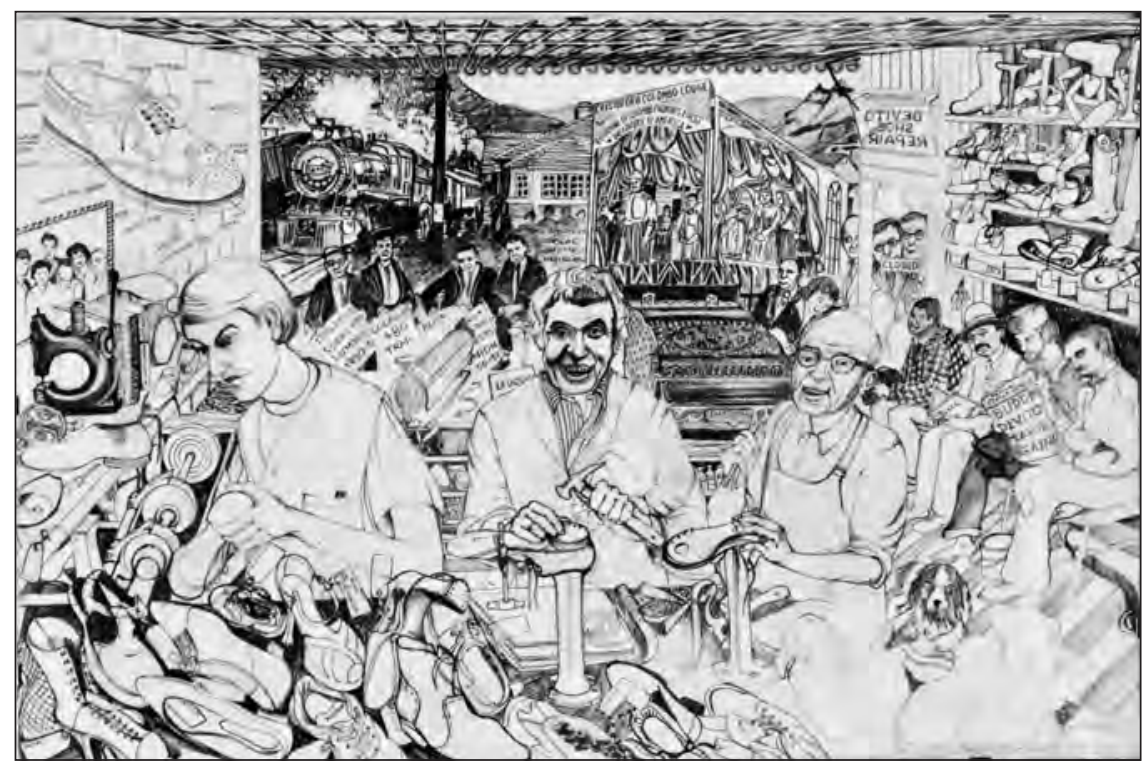

F. E. "Buddy" DeVito, a veteran and local businessman, was hired as a temporary MineMill representative. He supported Local 480 against Steel. An active member of the Italian community in Trail, he was later elected mayor.

Illustration courtesy of Maureen Travers.

British-born Dennis Williams - perhaps borrowing a chapter from former editor Bill Curran's red-baiting playbook - provided more anti-Mine-Mill support to the Steelworker raid, comparing Communism's hammer and sickle to "Hitler's crooked cross." 71

The month held bad news for the Uswa. The Labour Relations Board had refused the Steelworker certification bid, arguing that some of the card signers were not in good standing. ${ }^{72}$ Millard and the other Steelworker leaders rejected the LRB decision, claiming that the board was afraid of repercussions in the mining and smelting industry and from the CPC. They argued against the "not in good standing" issue, a pivotal factor arising from the raiders' earlier error in not collecting initiation fees. The "Steelmen" called the decision "short-sighted" and pledged that "this key defense plant will be wrenched from the grip of the communist machine." ${ }^{73}$ Despite the LRB setback, the uncertified Steelworker Local 4281 resolved to "carry on the fight" to "purge

71. “Beat Them at Their Own Game!” TDT, 29 May 1950.

72. “Steel Certification Refused - Membership Said Not in Good Standing," TDT, 6 May 1950.

73. “Some Companies Dealing with Reds to Save a Few Cents, Say Steelmen," TDT, 12 May 1950. 


\author{
Harvey Murphy signing \\ collective agreement for \\ Local 480 in Trail, BC. \\ Local 480 Archives, Trail, BC. \\ Courtesy of USW Local 480.
}

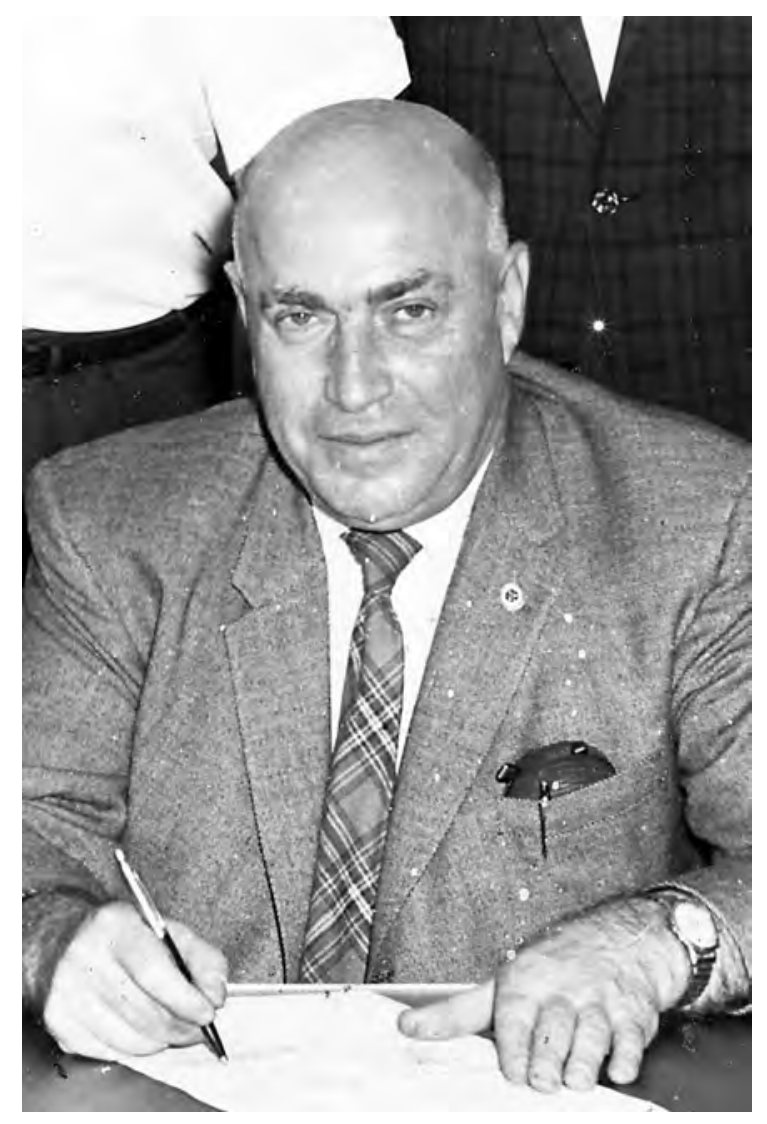

a communist-controlled organization as the bargaining agent for the workers of Trail." 74

Local 480 negotiators signed a new collective agreement on 23 May 1950. Two weeks later, Mine-Mill lawyer John Stanton filed a civil suit against Billingsley and two of his collaborators "for breaking their oaths and deserting their posts." 75 To Stanton, Billingsley represented the "harmful things that working people can be induced to do to one another" when guided by "an aggressive, power-hungry group of union leaders." 76 For Local 480 loyalists, Billingsley had become a quisling, a president determined to destroy the union. In summarizing the situation that Stanton had witnessed, King recalled,

74. “Appeal by Steel Is Ordered," TDT, 9 May 1950.

75. King, Red Bait!, 83. See also "Local 480 Case against Bolters up in Fall," DuN, 11 July 1950.

76. John Stanton, My Past Is Now: Further Memoirs of a Labour Lawyer (St. John's: Canadian Committee on Labour History, 1994), 116. 


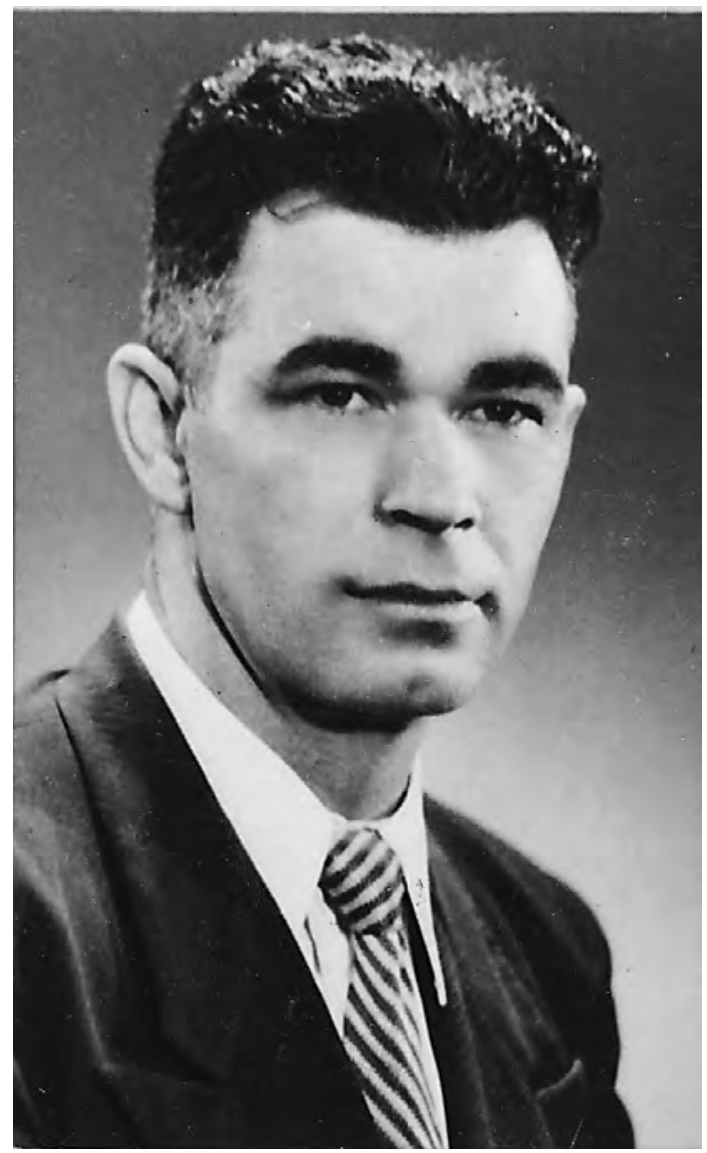

Al King was elected president and tasked with fighting off the Steel raiders.

BC District Union News, 11 February 1952, 2, call no. AW1 .R-2594, microfilm, Koerner Library, University of British Columbia. Reproduced by permission from United Steelworkers.

The forces against us were ... all united in trying to defeat the progressive elements who had founded Local 480 and who were still fighting for a dynamic union. All these forces (with the exception of the company, who tacitly welcomed Steel) would join the Steelworkers when they raided us. ... You can see what a damned devil's brew we had to contend with! ${ }^{7}$

King further argued that the Billingsley group had "emptied the bank account by paying each other full wages ... until there was nothing left." He also contended that Billingsley refused to have the local pay into the strike fund or the death benefit plan because "all the money was going directly to the Communist Party." ${ }^{78}$ Billingsley apparently saw it as a necessary step in erasing the local's red taint. Ironically, "the main reason for the split was the lack of power in the union to be able to support the men if there was a strike. They did not have 
any money in the strike fund." ${ }^{\prime 9}$ Yet Billingsley himself had gutted the local treasury, King stated.

When it was clear that the Steelworkers had lost the initial bid to usurp Local 480 , with the LR B deciding against the UswA application, Tillie Belanger, then acting secretary of Ladies Auxiliary Local 131, announced a "giant victory celebration" to acknowledge that "in spite of all the lies, red-baiting and general disruption Steel has indulged in, our workers ... have shown their true desire for democracy and honest trade unionism, not dictatorship of Millard and his raiders." ${ }^{0}$ The summertime ball saw "thousands dancing on the huge arena floor," Murphy reported, but when the band stopped playing and the victory celebration was over, it did not mark the end of the raids on Local $480 .{ }^{81}$ Its Communist leaders may have slowed the raiders momentarily, but the USWA was preparing to escalate the anti-red campaign anew.

As noted earlier, the raiding tactics used in Trail were comparable to those that the USWA brought to other Mine-Mill locations. Jensen, for example, describes the Steelworker raids in Utah, Arizona, the Connecticut copper belt, and Montana, arguing that some raids failed because the Mine-Mill local had a radical left-wing contingent, a strong history of militancy, and a dislike of outsiders. He further noted that Butte businesses and the city's primary employer supported Mine-Mill because they did not like the idea of the USWA taking Mine-Mill's place and perhaps usurping company control more than the smaller union..$^{82}$ The same may have been true of the Trail business community, as claimed by the Steelworkers, but there is much evidence to suggest that the company was on the side of the anti-Communists.

In her account of the raid on Local 117 in Montana, Mercier noted that "Montanan workers may have been anticommunist, but they clung to the ideals espoused by their independent, western-based union." In Aiken's account of a mid-1950s Steelworker raid on Mine-Mill Local 18 in Kellogg, Idaho, the anti-Communist strategy also failed, with some of the members calling it a "smokescreen" that employers used, while others joined the Shoshone County Anti-Communist Association. ${ }^{83}$ In Trail, some workers were anti-Communist, others were not, but a critical factor - one that set the Canadian community apart from the American one - was that many Trail workers also belonged to the left-wing CCF and they were adept at using it to win support for their Mine-Mill local, despite the anti-Communist views of the party leadership.

Interestingly, Mercier argues that the Steelworkers' anti-Communism did not convince a majority of Local 117 members to abandon Mine-Mill.

79. King, Red Bait!, 75.

80. “Auxiliaries - Trail,” The Union, 5 June 1950.

81. “Trail Celebration Is Unqualified Success,” DUN, 11 July 1950.

82. Jensen, Nonferrous Metals, 277-278.

83. Aiken, Idaho's Bunker Hill, 139. 


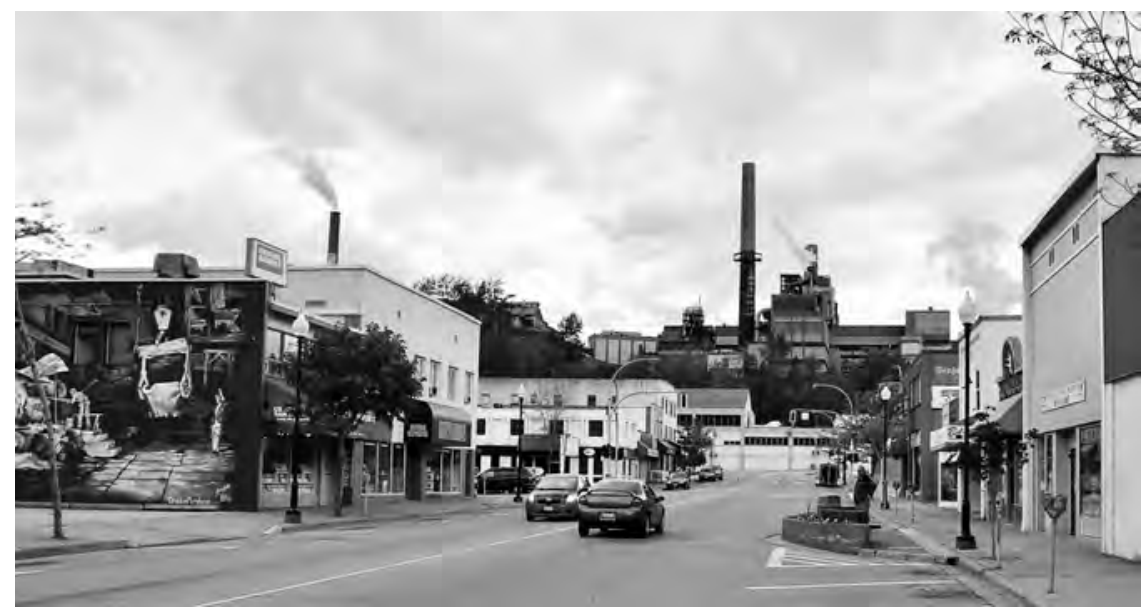

Trail today with Cominco smelter overlooking the city. Mural (left) shows lead furnaces where many workers suffered industrial diseases such as lead poisoning.

Photo by Ron Verzuh.

Instead, regional identity was responsible for the initial Uswa failure, with the Steelworkers complaining that Mine-Mill "had an advantage in extolling their union's historic presence in the West." ${ }^{84}$ The same could be argued for Trail with its history of labour activism, although red-baiting had an undeniable influence in favour of the Uswa. Critics suggest that the Anaconda local's capitulation to the USWA "assured the rapid demise of Mine-Mill." 85 While this may have been the case in the United States, Canadian locals, including Local 480, fought hard to retain their Mine-Mill status. In Trail, that struggle would soon entail engaging in battle with the Steelworkers a second time.

By July 1950, Local 480 leaders faced a new round of red-bashing partly due to their outspoken opposition to the Korean War after the CCF convention endorsed a United Nations task force being sent to protect South Korea from Communist aggressors. The decision "inflamed the left," Benjamin Isitt notes, but left-wing delegates were unable to overturn the decision. ${ }^{86}$ The convention also rejected the Stockholm Peace Petition to ban the atomic bomb, even though several members of the $\mathrm{BC}$ Legislative Assembly, including the pro-labour Leo Nimsick, had signed it. ${ }^{87}$ Local 480's King was aware that

84. Mercier, "Instead of Fighting," 473.

85. Mercier, "Instead of Fighting," 478.

86. Isitt, Militant Minority, 94.

87. For more on the petition and its negative public reception, see Robbie Lieberman, The Strangest Dream: Communism, Anti-Communism, and the U.S. Peace Movement, 1945-1963 (Syracuse: Syracuse University Press, 2000), 88-98. 
"those of us who supported it were called 'reds' and 'dupes' of the Soviets." 88 Nevertheless, the leadership directed much effort to supporting the local peace movement. By mid-August, the Times's Williams was calling the petition - which Local 480 had endorsed - "a piece of communist trickery." ${ }^{9}$ That autumn, the UswA won a reprieve from the BC Supreme Court when the union successfully challenged the LRB decision to disallow its certification bid. The ruling forced Local 480 to prepare for yet another LRB vote to determine which union would represent workers in the smelter city. ${ }^{90}$

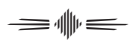

EARLY IN 1951, LOCAL 480 member Chuck Kenny reminded readers of his Cheerful Cynic column that it was the time of year when

the Trail Times gets the red ink out of moth balls, the RahRah gang of last February 9 gets free radio time (paid by honest workers) to practice elocution over the ether waves, and the citizens of Trail and district are entertained for a few weeks by watching a minority group of wage earners trying to cut their own throats with a red herring. ${ }^{91}$

Meanwhile, Local 480 had asked the BC Supreme Court to hear its civil suit against Billingsley and two of his confederates, Laurie Hamilton and L. R. Bailey, on a charge of failing to carry out their elected duties. ${ }^{92}$ For the UswA's part, it had asked for a representational vote, and in mid-March the court ordered the LRB to rehear the Trail case. ${ }^{93}$ Then, on April Fool's Day of 1951, the USWA raiders found an ally in their next attempt to unseat Local 480.

Six years after the Times had told its readers about the role the Trail smelter had played in the production of the atomic bomb, a young Canadian journalist named Pierre Berton published a feature article in Maclean's magazine that seemed designed to boost the Steelworkers' raid chances. The article claimed that the "red" union in Trail was controlling workers at a secret plant that produced heavy water, a material destined for use in the Manhattan Project. The article was crackling with sinister reminders that harkened back to Soviet cipher clerk Igor Gouzenko's spy revelations of 1945 and the subsequent FBI arrests. Berton's article brought the paranoia of the Cold War right to the doorsteps of Trail residents, informing some of them, perhaps for the first time, of the real purpose of the US-financed plant codenamed Project 9. Berton reminded readers that "the reds are still on top in a fight that could involve our

88. King, Red Bait!, 63.

89. “A Pledge to Sabotage," TDT, 11 August 1950.

90. "Saunders and Steelworkers Win in Supreme Court Case," TDT, 21 September 1950.

91. “It's the Steelworkers and Company vs. Mine, Mill,” DUN, 26 February 1951.

92. "Supreme Court at Rossland to Hear Local 480 Suit," TDT, 3 March 1951.

93. “Court Orders Labour Board Rehear Trail Labour Case,” TDT, 17 March 1951. 
security." 94 A month after the article appeared, the Cheerful Cynic responded for the union sarcastically noting that Local 480 had "poured him [Berton] a flagon of vodka with Joe Stalin's compliments" and he "was soon leading us all singing the 'Red Flag." 95 The District News columnist then "asked if the Steel Workers were paying his [Berton's] expenses."96

Like other mainstream journalists as well as the Steelworker raid leaders, Berton was invoking patriotism as a raid weapon, one that had particular appeal in the Cold War United States. Reflecting on the Steelworker raiders' claim that Mine-Mill members were unpatriotic, Morris Wright, the longtime editor of Mine-Mill's The Union, argued that the raid had degraded the labour movement and "brought the raiders into ever closer collaboration with employers and their stoolpigeons, antiunion politicians, vigilantes, the antilabour press, and backward workers who identified their interests with the employer." ${ }^{97}$ The idea that they were unpatriotic, coupled with years of redbashing, rankled Local 480 members, many of whom had served with honour during the war.

A month after the Berton article appeared, Local 480 reds got some longsought-after good news: the LRB had rejected the USWA's reapplication for certification and confirmed Local 480 as the legal bargaining agent for Trail's smelter workers. Refusing to accept both the order of Supreme Court Justice John V. Clyne and the advice of the Times, the board's rejection came "because the applicant has failed to prove that a majority of employees in the bargaining unit applied for are members in good standing of the applicant union." 98 Regarding allegations that Local 480 was "communist-dominated," the board said it could find no evidence to support that Steelworker claim. The ruling enraged the labour movement establishment. Despite the LRB's being part of the Fordist accord and the state-managed containment of postwar labour, the decision indicated that their efforts at objectivity might occasionally aid left-wing unions. The ruling also troubled a pair of Vancouver CCL leaders, who called the LRB a "political Gestapo," 99 and CCL president Mosher dubbed the decision a "denial of basic democratic rights." 100 The District News said

94. Pierre Berton, "How a Red Union Bosses Atom Workers at Trail, B.C.," Maclean's, 1 April 1951, 7-9, 57; quotation from p. 57. For a detailed account of the heavy water plant, see Ron Verzuh, "Blaylock's Bomb: How a Remote British Columbia City Helped Create the World's First Weapon of Mass Destruction,” BC Studies 186 (Summer 2015): 95-124.

95. “The Cheerful Cynic," DUN, 30 April 1951.

96. “MacLean's Mistake,” DuN, 30 April 1951.

97. Morris Wright, "Raiding Mine-Mill," in Ginger and Christiano, Cold War against Labour, 612.

98. “Labour Board Refuses to Rehear Steel Application,” TDT, 7 May 1951.

99. “CCL Unionists Score Labour Relations Board,” TDT, 9 May 1951.

100. “CCL Says Ruling Denial of Rights,” TDT, 10 May 1951. 
Mine-Mill battles the Canadian Manufacturers' Association (CMA) "Citadel." BC District Union News, 24 March

1953, 2, call no. AW1 .R-2594, microfilm, Koerner Library,

University of British Columbia. Reproduced by permission from United Steelworkers.

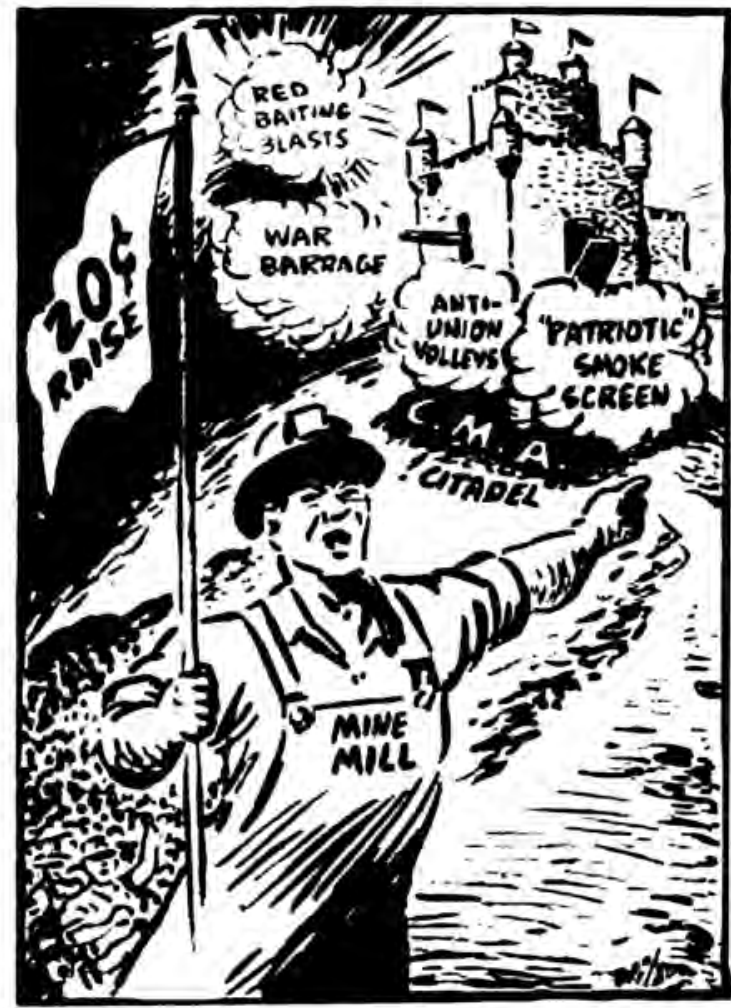

the board decision had "completely demolished" the uswa case and damned the Steelworkers and their allies for "using blackmail" on Local 480. "Their own stock-in-trade, red baiting, reached the most ridiculous depths" as "their red smear" spread even to the LRB and the CM\&S. ${ }^{101}$ Gargrave, seizing on the possibility that fallout from the Berton article might reinvigorate the Steelworkers' red-baiting strategy, said the decision meant the "workers now must choose whether they want to pay the money into a communist-controlled independent union or a legitimate union." ${ }^{102}$ He bought ad space in the Times to criticize the local for the slowness of negotiations, its low wage demand, and a dues checkoff plan negotiated by Murphy that Gargrave saw as a means to "force every worker - Mine-Mill supporter or not - to pay into

101. “Editorial - They Got Their Due," DUN, 28 May 1951.

102. “Dues," TDT, 9 June 1951. 
their [Mine-Mill's] treasury." ${ }^{103}$ When Local 480 settled for a 17.5-cent raise, ${ }^{104}$ Gargrave noted that the company "got off very lightly with Mine-Mill," but he refrained from further ideological sabre rattling. ${ }^{105}$

In September, the CCL leadership continued to purge its Communist-led affiliates, expelling the International Fur and Leather Workers Union (IF LWU) after a "clamorous uproar from left-wingers" at its annual convention. The IFLWU was late to join the other red union pariahs, but the expulsion might have raised more Mine-Mill ire, for as Joan Sangster has noted, the American Federation of Labour's Amalgamated Meat Cutters and Butcher Workmen Union (AMCBWU) took a similar approach to the Steelworker raiders in that it "tried to entice workers away from the IFLWU by stressing two issues: it claimed to be far superior at bargaining ... and it relentlessly pressed home a patriotic [anti-Communist] appeal."106 Mine-Mill had repeatedly rejected both claims, but that did not stop CCL secretary Pat Conroy from supporting Steelworker tactics. He also decried the LRB's refusal to certify the USWA in Trail, noting that the board was acting "in collusion with a communist union to break a CCL union."107

Earlier, both the UswA and Local 480 presented briefs to hearings on amendments to the BC Industrial Conciliation and Arbitration Act (ICA). Gargrave used the Steelworkers' brief to again condemn the LRB refusal. ${ }^{108}$ Local 480's submission called for many of the same changes that have long been accepted in the modern trade union movement. ${ }^{109}$ For its part, the CM\&S proposed that the act be "amended to prohibit communists from holding office in a labour organization or representing any labour groups in collective bargaining." 110 The Times applauded the company brief as a "masterpiece" that "struck a necessary blow" at Communist union leaders. ${ }^{111}$ The next day Murphy attacked the company's main proposals, in particular, the one requiring that union leaders sign affidavits similar to those issued under the Taft-Hartley Act. Murphy concluded that such an amendment would result in a "reign of suspicion, fear, and thought control." 112 Gargrave also went on the attack, again criticizing the

103. “Wages Are Your Business," TDT, 1 June, 1951; “More Wages ... What about Them?” TDT, 16 June 1951.

104. “Cominco and Union Agree On 17.5-Cent Hourly Boost," TDT, 30 June 1951.

105. “Letter - Gargrave Replies,” TDT, 26 July 1951.

106. Joan Sangster, “Canada’s Cold War in Fur,” Left History 13 (Fall/Winter 2008): 10-36, 18.

107. “CCL Floors Red Fringe in Opening Meet Tussle,” TDT, 18 September 1951.

108. “Steel Statement Hits Labour Relations Board," TDT, 7 September 1951.

109. “Local 480, Civic Union Briefs End ICA Session,” TDT, 8 September 1951.

110. “Cominco Would Bar Reds from Union Office,” TDT, 6 September 1951.

111. “A Blow for Mr. Murphy," TDT, 10 September 1951.

112. “Murphy Blasts Cominco's Proposals to ICA Board," TDT, 7 September 1951. 


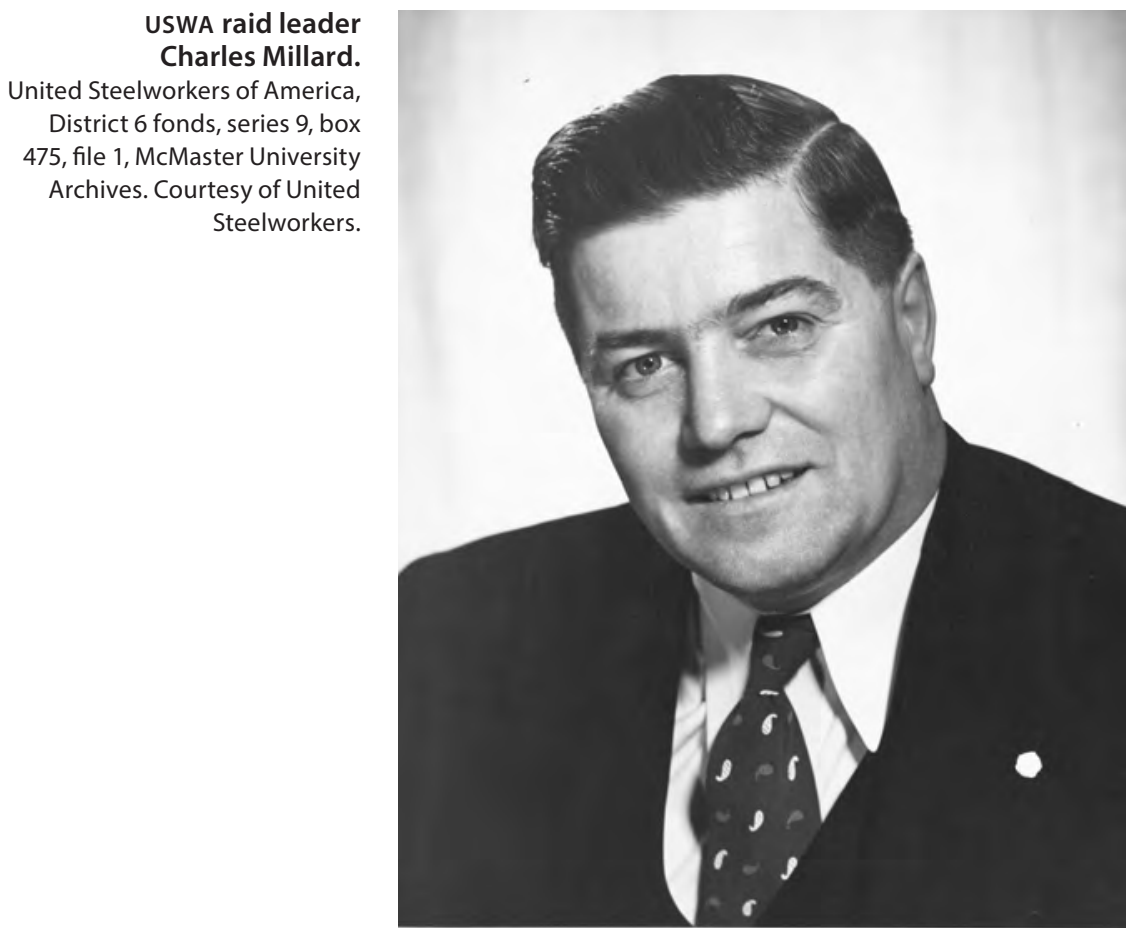

LRB for its Trail decision. With regard to a proposed dues checkoff formula, he argued that the company was guilty of accepting a ruling that would "voluntarily grant approximately $\$ 14,000$ a month to a suspect communist[-] controlled union."113

Elsewhere, the CCL was besieged by a series of top-drawer executive resignations associated with a major power struggle between the Steelworkers' Millard and Conroy. ${ }^{114}$ The acrimonious internal debate took some of the pressure off raid-weary Mine-Mill. Now the Steelworker leader would be forced to focus on consolidating his power base, but the respite would be brief. The raid would soon be on again with renewed vigour, but Murphy took advantage of the pause to claim that Millard had admitted to the Vancouver Sun that he had purchased the right to raid Mine-Mill, paying $\$ 50,000$ to the CCL. The raid, Murphy argued, "was part of a miserable sell-out by the CCL big shots, secretly conniving with Millard - a cash sale - selling the workers in the metal mining

113. “Letter: Steel's Opinion,” TDT, 13 September 1951.

114. “Third CCL Official Walks Off Job in Leadership Split," TDT, 22 September 1951. 


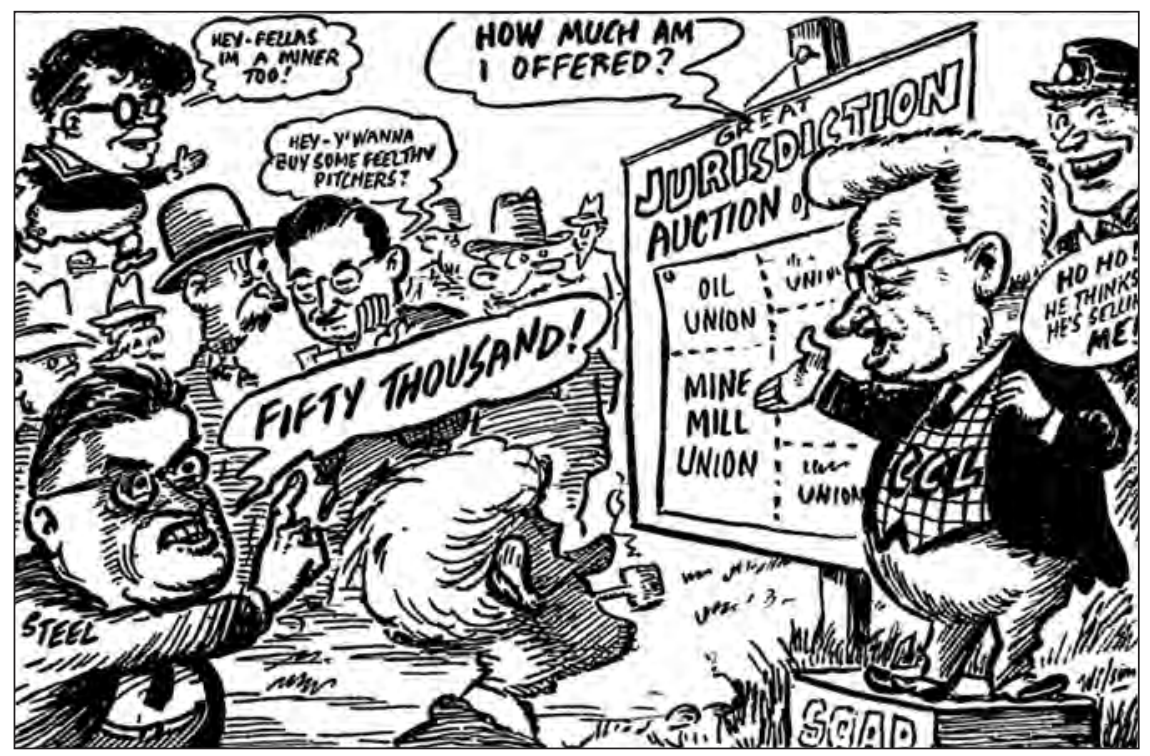

Raid leader Charles Millard offers CCF president Aaron Mosher $\$ 50,000$ for the right to raid Local 480.

BC District Union News, 7 March 1950, 5, call no. AW1 .R-2594, microfilm, Koerner Library, University of British Columbia. Reproduced by permission from United Steelworkers.

industry." 115 Murphy's new evidence was not clear from the Sun article and did not deter the raiders. ${ }^{116}$

In October, Steelworker Local 4281 announced that it had launched a twomonth drive to recruit Local 480 members. Gargrave spoke of a "healthy" membership in Trail and "surprising success" in the early days of this new raid. Local 480's King told the Times that "Steel's campaign is nothing to be alarmed at" and that Local 480 leaders "are confident the workers will stay with Mine-Mill."117 Murphy announced that the UswA's James "Shakey" Robertson, a former miner from Cumblerland, BC, had arrived in Trail to help Gargrave "maintain the disruption which has already cost the United Steelworkers over half a million dollars of the workers' money." Robertson, a former union secretary, was "doing a Hladun," Murphy charged, "his stock-in-trade being that he is a turn-coat Communist."118

115. “The Truth Is Out,” DUN, 28 September 1951.

116. “Battle with Murphy Costs Half-Million,” Vancouver Sun, 22 September 1951.

117. “Steel Union Plans Intensive Campaign; Mine-Mill Unconcerned,” TDT, 29 October 1951.

118. “A New Deal for Steel?” DUN, 31 October 1951. Former Communist turned anti-red John Hladun had visited Trail to denounce Murphy as a Communist. 
In early November, the Local 480 executive faced yet another setback when the company laid off three shop stewards for leading a wildcat strike in the lead smelter. ${ }^{119}$ A thousand members picketed the plant gates to protest, and Ladies Auxiliary Local 131 distributed leaflets saying "Put the stewards back to work!" and "No more unjust firing of our union brothers." ${ }^{20}$ At the same time, Murphy was threatening a slander suit against the UswA with regard to a scuffle at the smelter's main gate. A Steelworker Local 4281 member had been handing out leaflets to promote the raid when an unidentified Mine-Mill member approached him. The incident "flared into a fist fight" in which the USWA member was badly bruised and required six stitches. In a radio broadcast soon after the altercation, the USWA's Robertson claimed that Murphy "organizes with violence."121

In late November, Local 480 asked Mr. Justice J. O. Wilson to decide on the conspiracy charges that Mine-Mill had brought against Local 4281 executive members. Local 480 contended that the Billingsley leadership had conspired against the welfare of members in failing to honour their contracts as Local 480 executive holders when they abandoned their posts to join the Steelworkers. E. L. "Les" Walker and J. A. MacDonald had brought the charges on Local 480's behalf. ${ }^{122}$ For Local 480's Communist leadership this was perhaps an odd move, relying on the courts to decide on a local leadership matter rather than applying the Mine-Mill constitution regarding discipline. The same week, the Times took issue with the LRB, charging that its actions regarding the ongoing question of the USWA's certification application were "cloaked in secrecy." 123

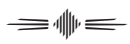

IN LATE JANUARY 1952, perhaps assuming that its message to the BC government about ICA amendments had not been sufficiently heard, the CM\&S published another full-page ad in the Times, this time under the heading "Communism." It was an aggressive new tone from a company that had stood by more or less quietly as the bitter union rivalry unfolded. Now it seemed to turn on Mine-Mill. With the ICA hearing board unlikely to accept its proposal to disallow Communist union leaders, the CM\&S appealed to public sentiment. Outlining what it was legally permitted to do in its efforts to fight Communism, the company then stated that "it is our right to refuse to accept for permanent employment Communists or other subversive characters."124

119. “Cominco Discharges Three Stewards over Walkout,” $T D T, 9$ November 1951.

120. “Arbitration Board Deals with Firing of Trail Workers," PT, 23 November 1951.

121. “Unionist Hurt, Slander Suit Threatened," TDT, 13 November 1951.

122. “Legal Dispute Delays Union Case, Rossland,” TDT, 27 November 1951.

123. “The Labour Board,” TDT, 29 November 1951.

124. “Communism,” TDT, 26 January 1952. 
The Times published a front-page report on the ad, stating that the LRB had not addressed the problem, although it suggested that the board had acknowledged Local 480 was "communist-dominated." 125 On its editorial page, the paper was more pointed: "any employer of labour has a responsibility both to his own business and to his country to guard against employment of those who ... would follow the dictates of the kremlin [sic] or any other foreign power."126

As Local 480 prepared to continue its war with the Steelworkers, other Mine-Mill locals came to its aid. Local 651 at Kimberley's Sullivan Mine, for example, placed an ad in the Times urging Trail workers to "cast forth the disruptive elements." ${ }^{27}$ Local 649 at Copper Mountain, BC, warned Steelworker raiders that if they tried to bring their "union busting tactics" to their local, "a warm welcome would await them. ... In fact, it would be a rather hot welcome." ${ }^{128}$ Meanwhile, Local 480 lost its suit against Billingsley and his two executive members, and Supreme Court Justice Wilson ordered Mine-Mill to pay all damages. ${ }^{129}$

That March, Local 480 executive members shifted their attention to the annual round of negotiations. At a pre-bargaining meeting, the USWA, having reapplied for certification two days earlier, was criticized for "continued disruption' on the eve of bargaining." 130 The UswA, meanwhile, advertised that it had again signed a majority of the smelter workers and was offering them a chance to join a union that was not "unduly dominated by members and supporters of the world Communist movement."131 Murphy called the Steelworker raiders liars for claiming to have signed a majority of workers and accused them of splitting the bargaining unit. ${ }^{132}$

The Times continued to back the UswA raiders, charging that MLA Nimsick had "compromised" the CCF by siding with Mine-Mill over the Steelworkers, the party's major union backer. ${ }^{133}$ By mid-month, an LRB vote determined that Local 480 had won the right to continue representing the plant workers in the smelter city. Al King recalled the moment:

Some of our people, including Murphy and I, went around town and up and down the Gulch playing bocce ball with the Italian guys, meeting them in the beer parlours and passing these "Vote Mine Mill" buttons around. The Steelworkers were either so sure of themselves

125. "Cominco Says No Jobs for Communists," TDT, 26 January 1952.

126. "No Communists," TDT, 28 January 1952.

127. “To All Workers on the Hill," TDT, 16 January 1952.

128. “To The Workers on the Hill," TDT, 18 April 1952.

129. “Mine-Mill Damage Action Dismissed," TDT, 4 February 1952.

130. “The Hollinger Story," TDT, 3 March 1952.

131. “A Statement...," TDT, 11 March 1952.

132. “Mine-Mill to Fight Steel's Bid for Bargaining Rights,” TDT, 22 March 1952.

133. “CCF Compromised," TDT, 15 May 1952. 
or else so unprepared they didn't even bother to put out a pamphlet. In the secret ballot vote the next day, the guys on the job responded magnificently. Steel was caught flat-footed. We had the Labour Relations Board vote and we beat 'em. ${ }^{134}$

Finally, the struggle for union supremacy in Trail seemed about to end, although the vote was worryingly close: Mine-Mill with 1,949 to the UswA's 1,669. Still, it was decisive enough that even the Times called on Steelworker Local 4281 members to rejoin Local 480 so as to present "a united bargaining front." 135 Seeming to cede the high ground to Local 480, it added,

Labour's hand is strengthened by this decisive result and the good of the community is served by the elimination, which it is hoped will result [in an end] of the constant bickering in the jurisdictional dispute which has flared in Trail for two years. ${ }^{136}$

In truth it had been longer than two years. Since the late 1940s, the Steelworkers had been positioning themselves for a raid on Local 480, clandestinely at first and then in greater openness starting in February 1950. Now the labour war was finally coming to an end. "Red-Tinged Union Triumphs at Trail," read the Vancouver Sun's headline on 15 May 1952. The vote "ended the biggest, longest and most bitter jurisdictional fight in B.C. labour history," the daily added. ${ }^{137}$

$$
\equiv \|
$$

Like other Raids in North America during labour's 1950s Cold War, the Trail raids epitomized a monumental struggle that sadly pitted two unions against each other and left the company relatively unscathed and perhaps even strengthened in the process. Deception and secret collaborations marked the contest. Court hearings revealed anti-Communist biases on the part of some members of the bar. The LRB hearings were the scene of some unscrupulous actions by both unions but the board's decisions held, bringing more criticism from anti-Communist newsrooms like the Vancouver Province. ${ }^{138}$ King gives much of the credit to Murphy for orchestrating the victory over the Steelworkers. Murphy was "brilliant, tactically," King wrote, but such praise was not shared among the established labour leadership. ${ }^{139}$ For the most part they despised Murphy. So did the business press, which characterized Murphy as an opportunist.

Mine-Mill lawyer John Stanton had a similar view of Murphy, but he considered that Murphy and Local 480 had experienced "the full fury of a Steel

134. King, Red Bait!, 111.

135. "Mine-Mill Wins Union Vote in Trail," TDT, 15 May 1952.

136. “Decisive Vote," TDT, 16 May 1952.

137. Fred McNeil, “Mine Mill Keeps Trail,” Vancouver Sun, 15 May 1952.

138. Jean Howard, “This Column," Vancouver Province, 16 May 1952.

139. King, Red Bait!, 114. 
raid backed by the leaders of the Cooperative Commonwealth Federation and the CCL." 140 Declaring that the CCF would gain electoral support from a Steelworker win, Stanton argued that the CCL "made Mine Mill a punching bag by suspending it."141 For the Mine-Mill lawyer, the Uswa lived up to its cold warrior reputation. Stanton observed that being "unable to attack MineMill's record as a good, fighting union which represented its members well, Steel resorted to innuendo and to anti-communist ploys." ${ }^{142} \mathrm{He}$ concluded his account this way:

Failure at Trail caused no change in policy for Steel. To that union it was only a small tactical loss. The main strategy of raiding went on. ... To speak of "organizing" workers who were already well organized may sound irrational, but in the crazy logic of the Cold War, "anything goes."

By July 1952, a huge US steel strike had finally been unclenched and it would preoccupy Millard and other Canadian Steelworker leaders for 55 days. By then Trail might have seemed ancient history to the Canadian Steel director. ${ }^{144}$ By year's end, the US Senate had issued a report urging rank-and-file Mine-Mill members to revolt against their red leadership. After reading it, Murphy stated that BC Mine-Mill members would have "nothing but contempt" for it. ${ }^{145}$ And he was right.

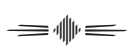

Mine-Mill's Trail RAID ViCTORY represented a brief moment of resistance to the national labour leadership's grand plan to reshape the North American movement as it accepted the postwar legal compromise. In Trail, the plan backfired partly because outsiders had orchestrated it. Yes, the Billingsley group was locally based, but it had been willing to transfer Local 480 to what was perceived as a mega-union that would have little allegiance to Trail. Like the Communists in the small Montana farming community that Gerald Zahavi studied, Trail Communists fought for "alternate social, intellectual, and psychological spaces within the greater society around them." 146 But they

140. Stanton, My Past, 102.

141. Stanton, My Past, 103.

142. Stanton, My Past, 106.

143. Stanton, My Past, 115-116.

144. Charles Millard, interview by Jack Spiese, 13 February 1968, 25, Historical Collections and Labour Archives, Eberly Family Special Collections Library, Pennsylvania State University, University Park, Pennsylvania.

145. "Mine and Smelter Workers Urged to Oust Red Leaders," Vancouver Sun, 30 December 1952.

146. Gerald Zahavi, “'Who's Going to Dance with Somebody Who Calls You a Mainstreeter': Communism, Culture, and Community in Sheridan County, Montana, 1918-1934," Great 
posed no real threat to the community. In fact, Local 480 proved to be an exemplary practitioner of homegrown social unionism, or what Mercier called community unionism. The leaders were part of the local political culture and they often supported progressive social causes, even when it meant sidestepping unwanted CPC policy. They took action based on what made sense locally. Murphy, King, and others may have been consummate red foot soldiers, but they did not march in lockstep with any national political party. The local membership continued to support CCF MP Herridge, who had backed them in the raids. That served as partial proof of their willingness to travel the political path that would prove most advantageous. But the local's Communist leaders continued to nominate Communists at election time.

Mine-Mill propaganda helped instill the view that the USWA, the CCL, and to an extent even the federal and provincial CCF were unwanted interlopers in Trail. Many workers perceived them as hungry for the union dues and votes of smelter workers and willing to join with the local array of anti-Communists to ostracize workers because of their beliefs. This was not unlike the response of hundreds of other industrial workforces that found themselves invaded by the USWA in the 1950s and 1960s, but Trail succeeded where other resisters failed. Similarly, many locals had the support of ladies auxiliaries, but none was stronger in its political support for the Communist leadership and against the raiders than Trail's Ladies Auxiliary Local 131. The local began in 1944 with several Communists in its leadership ranks. One, Tillie Belanger, ran as a Labour Progressive Party (LLP) candidate in the 1953 federal election. When the USWA raiders disregarded the women's support for Mine-Mill, it diminished their chances of success.

As with its willingness to fight for peace, the Trail local revealed a strength that the Cold War had already subdued in other Mine-Mill locals. In Kellogg, Idaho, for example, "fears of communism had deep roots," notes Aiken, and charges of Communist influences on Mine-Mill Local 18 had "profound effects." ${ }^{147}$ Trail Communists did not face the same intensity of McCarthyite anti-Communism that such US locals did, and this perhaps helped them to not succumb to those negative social forces. Instead, they developed an antiraiding strategy that included creative cultural tactics redolent of the popular front in the 1930s. In particular, they supported singer and civil rights activist Paul Robeson's efforts to restore his US passport and they sponsored the pro-labour blacklisted movie Salt of the Earth. ${ }^{148}$ Perhaps its isolation in the

Plains Quarterly 16 (Fall 1996): 251-286, 272.

147. Aiken, Idaho's Bunker Hill, 137.

148. For the Robeson account, see Laurel Sefton McDowell, "Paul Robeson in Canada: A Border Story," Labour/Le Travail 51 (Spring 2003): 177-221. For Mine-Mill's role in promoting Salt, see Ron Verzuh, "Mine-Mill's Peach Arch Concerts: How a 'Red' Union and a Famous Singer-Activist Fought for Peace and Social Justice during the Cold War," BC Studies 174 (Summer 2012): 61-99. 


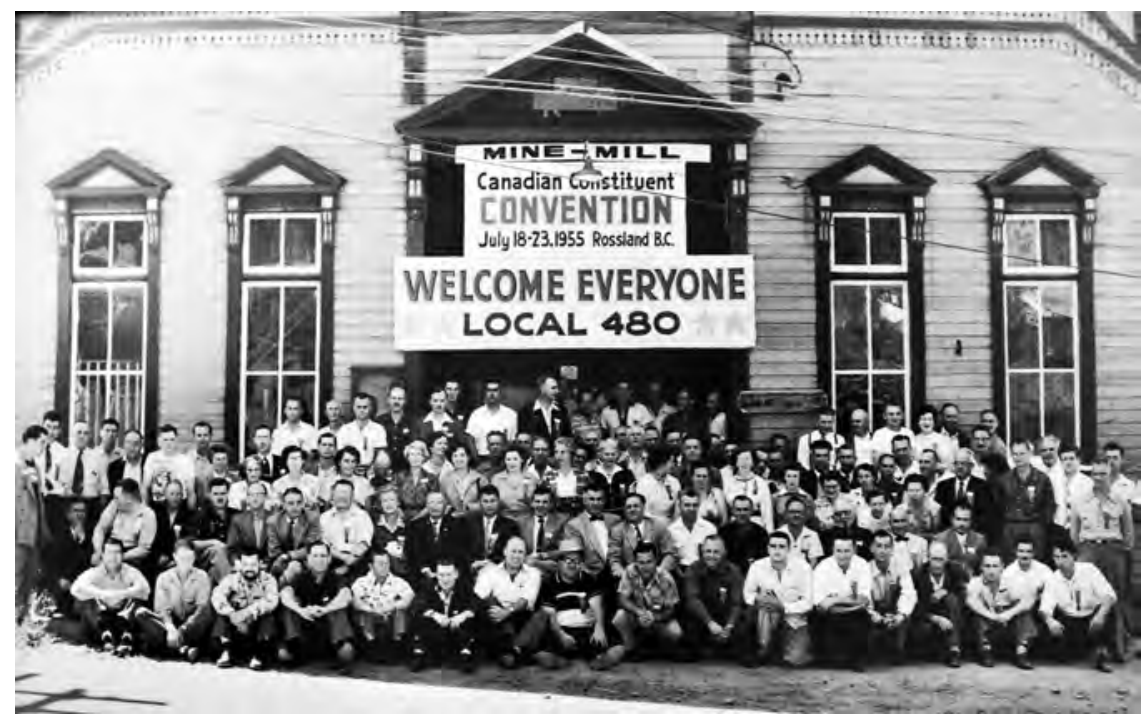

Local 480 hosted the founding convention of Mine-Mill Canada in the historic Rossland Miners' Union Hall, built by Local 38 of the Western Federation of Miners, Mine-Mill's predecessor, in 1898.

Local 480 Archives, Trail, BC. Courtesy of UsW Local 480.

Kootenay mountain ranges helped protect Local 480 from a full McCarthyite onslaught, but the Canadian government's silent complicity with US authorities suggests that this, as with other raided communities, was not the case. Indeed, Murphy was an ideal target that enticed the Cold War raiders to the smelter gates. Nevertheless, the local leaders stood behind him and he behind them.

Two years after the raids had finally desisted, and with the full compliance of the international union, Canada's Mine-Mill locals formed their own autonomous national union. In 1955, they met at the miners' union hall in Rossland, a historic venue built by WFM Local 38 members in 1898. Murphy was elected vice-president of the new union and was appointed editor of the Mine-Mill Herald, a new monthly that continued to fight against Steelworker raiding for another twelve years. King presided over the Trail local from 1950 to 1960, opposing Steelworker raiding through his editorials in the Local 480 Commentator. In the late 1950s, when the Steelworkers raided Mine-Mill Local 598 at INCO in Sudbury, Local 480 made the largest donations to the anti-raid war chest.

Perhaps it seems melodramatic to conclude that in this union contest, the Mine-Mill David conquered the Steelworker Goliath. Solidarity and unity won out over the Steelworker raiders, with Local 480 standing its ground regardless of societal pressure. In truth, circumstances and rapidly transpiring 
events, like the huge Steelworker strike in the United States and exposure of McCarthy's own excesses, also had much to do with it. It might be viewed as sentimental to suggest that the Steelworkers were defeated by a more pronounced sense of labour history and local union pride. But in a way, that pride was a large part of Mine-Mill's appeal in the mining West. As Jensen observed, Mine-Mill "understood the basic desire of the hard-rock miners and smelter workers for their own union and for rank-and-file participation and expression, and capitalized on it." 149 But despite local union loyalty and victories like the one in Trail, the raids diminished the power of both Mine-Mill and its antagonists in the USWA and the CCL. "In crushing the Communists," Harvey Levenstein concludes, "the labour movement also lost unionists who, despite their short run disrepute, in the long run would have helped increase the stature of organized labour in the eyes of the public as well as the workers." 150 There is no way to know if that is true, and others have suggested that the path of Communist trade unionists was a ruinous one. "Men and women who courageously stood up to the American status quo ... were unable to think critically about Stalinism," writes Will Cooley. "Talented and dedicated leaders ... deluded themselves that the Party was building a more equitable America even as Stalinist crimes became impossible to justify."151 Were Local 480 leaders guilty of deluding themselves? Some of them were, of course, but others simply shaped their politics to suit their rank-and-file needs.

Local 480 took on a giant, borrowing anti-raid tactics from some of its American counterparts and inventing some of its own. Its confrontation with the USWA and its allies illustrated the willingness of a majority of workingclass citizens to challenge the cold warriors in their midst and to oppose those forces threatening to undermine democratic control of their workplace. Big unionism, represented by top-down unions like the Steelworkers, had forsaken the once potent power that had existed during the nascent days of the CIO. Local 480 and Mine-Mill were seen as holdovers from that earlier era of shop-floor democracy and wildcat action. The leaders of the postwar labour movement, having rejected that style of unionism, accepted the anti-Communism of the McCarthy era and acted to dispose of its red affiliates. Trail defied them and won.

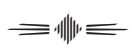

149. Jensen, Nonferrous Metals, 304.

150. Harvey A. Levenstein, Communism, Anticommunism, and the CIO (Westport, CT:

Greenwood Press, 1981), 331.

151. Will Cooley, "Communism, the Cold War and a Company Town: The Rise and Fall of UE Local 709," Labor History 55, 1 (2014): 86. 
To ThOSE IN Trail who had fought the Steelworker raids, it might have seemed a traitorous act when Mine-Mill merged with the USWA in 1967. Some never forgave Murphy for taking a job with the Steelworkers. "He let the bastards get to him," said Bill White, a fellow Communist labour leader. ${ }^{152}$ Others might not have blamed Murphy given the CPC's shifting union strategies. It might have seemed a betrayal to local concerns, but perhaps accepting a job with the much larger UswA was in keeping with the party's national political priorities. It might have seemed ironic that in the early 1970s a local breakaway group called the Canadian Workers' Union (CWU) raided Steelworker Local 480. Composed of smelter workers dissatisfied with the UswA's bureaucratic management style and lack of support for local concerns, the CwU's rebellious actions were reminiscent of those of the old Mine-Mill. In 1974, only a few years after the merger, the USWA strongly supported Trail workers during a lengthy smelter strike. Some lauded the union. Others said it was trying to redeem itself for the years of raiding and red-baiting. In the early 1980s, dissenters continued to raid Steelworker Local 480 under another Canadian union banner. ${ }^{153}$ It might also seem ironic to those who remember the raids that in early 2018, Ken Neumann, UswA national director, could be heard calling out the raiders at Unifor for an attempt to snatch members of UNITE HERE Local 75 in Toronto's hotel industry. "Raiding's inherent divisiveness ends up serving the interests of employers much more than it does employees," Neumann said. "Responsible unions long ago decided to give up raiding." ${ }^{54}$ As we have seen here, the Steelworker leader knows whereof he speaks.

152. White, Hard Man, 248.

153. For a report on the later raids, see Philip Resnick, "The Breakaway Movement in Trail," in Paul K. Knox and Philip Resnick, eds., Essays in B.C. Political Economy (Vancouver: New Star Books, 1974), 52-59.

154. Ken Neumann, "Union Raiding Is a Blow to Solidarity among Workers," Huffington Post, 2 February 2018, http://www.huffingtonpost.ca/ken-neumann/ union-raiding-is-a-blow-to-solidarity-among-workers_a_23349336/. 


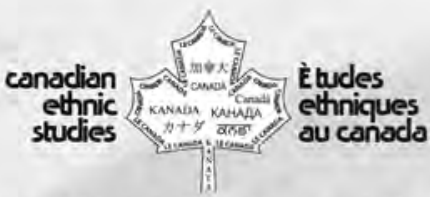

Canadian Ethnic Studies/Études ethniques au Canada

clo SS 909 Department of Sociology, University of Calgary, Calgary, AB, T2N 1N4

Telephone/Téléphone (403) 220.7372 Fax/Télecopieur (403) 282.9298

Email/Courriel: cesa@ucalgary.ca Web site/Site Web: https://cesa-scee.ca/ces-journal/

An interdisciplinary journal devoted to the study of ethnicity, immigration, inter-group relations, and the history and cultural life of ethnic groups in Canada. Issues also include book and film reviews, opinions, immigrant memoirs, translations of primary sources, an "ethnic voices" section, and an annual index.

Une revue interdisciplinaire consacrée a l'étude de l'ethnicité, des relations entre groupes et de l'histoire et de la vie culturelle des communautés ethniques au Canada. Tous les numéros comprendent des recensions de livres et de films, des opinions, des mémoires d'immigrants, des traductions de textes originaux, une section "voix ethnique s et, une fois par an, une bibliographie de l'année.

\section{Subscription rates/Frais d'abonnement: \\ Individual/régulier \\ Student/étudiant}

Institution/institution

One year/un an
$\$ 110.00 \mathrm{CAD}$
$\$ 70.00 \mathrm{CAD}$
$\$ 170.00 \mathrm{CAD}$

Outside Canada/hors du Canada

$\$ 120.00$ USD

$\$ 80.00$ USD

$\$ 170.00$ USD

The above rates include membership in the Canadian Ethnic Studies Association.

Le tarif ci-dessus correspond à la carte de membre de la Societé d'études ethniques au Canada.

Individual issues/un seul numero

\$35 CAD or \$35 USD outside Canada/hors du Canada

For further information, contact Canadian Ethnic Studies.

Pour plus de renseignements, veuillez contacter les Etudes ethniques au Canada.

The journal's web site is located at https://cesa-scee.ca/ces-journal/. It indudes a newsletter, book and film reviews, lists of books available for review, instructions on submitting articles and reviews, and other information.

Ladresse de la revue sur la Toile est https.//cesa-scee.ca/ces-journal/. Le site comprend un bulletin, des recensions de livres et de films, une liste des livres prêts à être recensés, des instructions concernant la soumission d'articles et de recensions, et autres renseignements.

\section{SPECIAL ISSUES AVAILABLE/NUMÉROS SPÉCIAUX EN VENTE :}

Integration of Immigrants and Temporary Migrants into the Labour Market in Quebec and Canada: New Perspectives on Contexts and Actors, 2017, 49,2

Dimensions of Immigration and Integration in Canada. 2016.48.3

Transforming Citizenship: Ethnicity, Transnationalism, and Belonging in Canada, 2015.47.1

Ethnic Identity Formation and Migrant Mobilities in Canada. 2014.46.2

Immigrant Integration. 2013.45.3

\section{REGULAR ISSUES INCLUDE/LES NUMÉROS RÉGULIERS COMPRENNENT :}

Nilum Panesar, Yolande Pottie.Sherman, and Rima Wilkes. "The Komagata Through a Media Lens: Racial, Economic, and Political Threat in Newspaper Coverage of the 1914 Komagata Maru Affair:" 2017. 49.1.

Augie Fleras. "Theorizing Micro-aggressions as Racism 3.0: Shifting the Discourse." 2016. 48.2.

Frédérick Nadeau and Denise Helly. "Extreme Right in Quebec?: The Facebook Pages in Favor of the "Ouebec Charter of Values." 2016.48.1

Anne-Marie Livingstone and Morton Weinfeld. "Black Families and Socio-economic Inequality in Canada." 2015. 47.3.

Basia Ellis. "The Production of Irregular Migration in Canada.' 2015. 45.2.

Shibao Guo. "Economic Integration of Recent Chinese Immigrants in Canada's Second-Tier Cities: The Triple Glass Effect and Downward Social Mobility" 2013,45.3. 